\title{
Leaching behaviour of elements from coal combustion fly ash: an overview
}

\author{
Maria Izquierdo $\mathrm{a}^{*}$, Xavier Querol $^{\mathrm{b}}$ \\ ${ }^{a}$ British Geological Survey, Keyworth, Nottingham NG12 5GG, UK \\ ${ }^{a}$ Institute of Environmental Assessment and Water Research, Jordi Girona 18-26, 08034 Barcelona, Spain
}

\begin{abstract}
Coal-based power generation produces over $750 \mathrm{Mt}$ of coal ash per year globally, but under $50 \%$ of world production is utilised. Large amounts of fly ash are either stored temporarily in stockpiles, disposed of in ash landfills or lagooned. Coal ash is viewed as a major potential source of release of many environmentally sensitive elements to the environment. This paper encompasses over 90 publications on coal fly ash and demonstrates that a large number of elements are tightly bound to fly ash and may not be easily released to the environment, regardless of the nature of the ash. This review provides an extensive look at the extent to which major and trace elements are leached from coal fly ash. It also gives an insight into the factors underlying the leachability of elements and addresses the causes of the mobility. The mode of occurrence of a given element in the parent coal was found to play an important role in the leaching behaviour of fly ash. The amount of calcium in fly ash exerts a dominant influence on the $\mathrm{pH}$ of the ash-water system. The mobility of most elements contained in ash is markedly $\mathrm{pH}$ sensitive. The alkalinity of fly ash attenuates the release of a large number of elements of concern such as $\mathrm{Cd}, \mathrm{Co}, \mathrm{Cu}, \mathrm{Hg}, \mathrm{Ni}, \mathrm{Pb}, \mathrm{Sn}$ or $\mathrm{Zn}$ among others, but at the same time, it enhances the release of oxyanionic species such as As, B, Cr, Mo, Sb, Se, V and W. The precipitation of secondary phases such as ettringite may capture and bind several pollutants such ash As, B, Cr, Sb, Se and V.
\end{abstract}

KEYWORDS: coal, fly ash, trace elements, mode of occurrence, leaching, solubility, oxyanions, $\mathrm{pH}$-dependence, ettringite

\section{INTRODUCTION}

In order to fulfil the future world energy demand, all energy resources may need to be utilised. Despite the efforts and the commitment for renewable power to account for a significant share of the total electricity supply, coal is still one of the most important electricity producing fuels. With growing energy demand, many industrialised and developing countries will continue to rely on coal for power generation in the decades to come. 
Any energy source brings with it some technological advantages and disadvantages, as well as some environmental benefits and problems. Coal-based power generation produces large amounts of fly ash worldwide. An estimated $780 \mathrm{Mt}$ of coal ash are produced every year (WWCCPN, 2011). Fly ash has been successfully used for many years in a wide range of applications including building material applications, asphalt, concrete pavements, soil stabilization, road base, structural fill, embankments, mine reclamation, mineral fillers or fertilisers, as well as small scale applications such as production of zeolites and geopolymers. However, it is most commonly used as a high-performance substitute for portland cement and as a clinker addition in the manufacturing of portland cement. The present situation is a long way from full utilisation of ash, in fact it is marginally under $50 \%$ of world production (WWCCPN, 2011). There are large amounts of fly ash either stored temporarily in stockpiles, disposed of in ash landfills or lagooned. The phase transformations that mineral matter in coal undergoes during high temperature combustion may render the trace elements in the original coal matrix susceptible to leaching (Jones, 1995). Some elements contained in fly ash are likely to be released from the storage/disposal/application site when ash comes in contact with water.

The ecosystem appears to be an excellent filtering machine that retains contaminants such as metals in its soil profiles (Négrel and Roy, 2002). However, the borderless nature of the environment could result in the transfer of pollutants into groundwater and river systems, either in dissolved or particulate form. This may pose serious threats for aquatic organisms, while metal inputs in groundwater resources may entail a significant health hazard. Moreover, with the development of technically advanced fly ash-based products, e.g. geopolymer matrices, the occurrence and behaviour of trace elements contained in ash is becoming of growing concern. The environmental performance needs to be understood when placing new products in the market.

Whether fly ash is landfilled, disposed in surface impoundments, lagooned or recycled into ash based-products, care should be taken as the total content of an element does not appear to be an accurate indicator of the potential environmental impact. The chemical properties of fly ash have been extensively studied and it is well known that fly ash contains a broad array of trace elements in concentrations $>50 \mathrm{mg} / \mathrm{kg}$, many of which are of environmental concern. Assessing the environmental performance of products based on the concentration of elements present in ash would provide unreliable and highly overestimated predictions of the risk level which inevitably would limit any fly ash application opportunities.

It is for this reason that the characterisation and prediction of metal mobility has attracted considerable attention. The tightening of environmental regulations and growing concern about health effects of exposure to heavy metals even at trace levels have driven a number of 
researchers to undertake studies on the dissolution of elements from fly ash. Most studies primarily focus on elements of major environmental concern such as $\mathrm{As}, \mathrm{Cr}, \mathrm{Pb}$ or Se among others, while overlooking other constituents (e.g. Be, P, W or Mo are poorly studied) considered as generally posing little risk to the environment; the latter, however, may have high environmental relevance locally.

Given the wide range of coal features such as rank, ash yield and chemical and mineralogical composition (inherited from the depositional setting), the different temperatures used in power stations and the different particulate control devices used worldwide, one might expect ash byproducts from different countries to have very little in common. However, it is striking to see in an extensive literature review that some general trends in the leaching behaviour of elements do emerge. The leached concentrations expressed in terms of absolute value may certainly differ, but the leaching behaviour appears to follow relatively common patterns. This suggests that the factors that control the leaching of elements from fly ash do not differ significantly regardless of the composition and characteristics of the ash. The understanding of the reasons underlying the mobility of an element is a key question for better control over environmental impacts in the wide variety of utilization and disposal practices. It may also assist in costeffective design of management strategies and in the decision making of regulatory agencies. This paper is intended to provide an extensive look at the leaching of most elements contained in coal combustion fly ash and an overview of the underlying factors controlling their mobility. The information is assembled from an extensive literature review and represents a global range of ash features, as the data evaluated were obtained from tests on fly ash worldwide.

\section{GENERAL ASPECTS}

In order to fully understand the leaching properties, it is important to bear in mind that fly ash is a heterogeneous material as the elements are not evenly distributed throughout. The mineral fraction in coal undergoes different transformations during and after combustion, namely decomposition, volatilisation, fusion, agglomeration or condensation (Jones, 1995). As the flue gas cools down after combustion, volatile elements such as $\mathrm{As}, \mathrm{B}, \mathrm{Hg}, \mathrm{Cl}, \mathrm{Cr}$, Se and most prominently $S$, condense on the surface of the fly ash particles, forming compounds with a variable solubility (commonly on the high side) and essentially combined with Ca. This results not only in a strong gradient of element concentrations within fly ash particles (Kukier et al., 2003), but also in a gradient of leachability. The surface layer of fly ash particles, only microns in thickness, contains a significant amount of readily leachable elements (Iyer, 2002) that, with the exception of $S$, stand out for being inherently more toxic at low levels than major elements. Alongside the above listed elements, $\mathrm{Cd}, \mathrm{Cu}, \mathrm{Mo}, \mathrm{Sb}, \mathrm{V}$ and $\mathrm{Zn}$ are also preferentially enriched on the surface, whereas $\mathrm{Ba}, \mathrm{Co}, \mathrm{Cr}, \mathrm{Mn}, \mathrm{Ni}$ and $\mathrm{Pb}$ tend to be more evenly distributed between 
the surface and the matrix (Jones, 1995). The elements enriched in the cores of fly ash particles are not directly exposed to leaching and therefore their releases are diffusion controlled and also dependent on the dissolution rates of the surface layers (Kukier et al., 2003). Surfaceassociated elements are therefore more susceptible to leaching in an aqueous environment.

The above surface/core partitioning is reflected in the composition of a typical fly ash leachate. The most prominently released elements are $\mathrm{Ca}$ and $\mathrm{SO}_{4}{ }^{2-}$, followed by $\mathrm{Cl}, \mathrm{Na}$ and $\mathrm{K}$ ( $\mathrm{Hjelmar}$, 1990) to a lesser extent, and then a large number of trace elements leached in levels generally $<10 \mathrm{mg} / \mathrm{kg}$. If conducting a column test or a multiple batch test, one can expect high conductive salt-rich leachates at early stages (Dudas, 1981; Querol et al., 2001), as these K$\mathrm{Ca}-\mathrm{Na}$ chlorides and sulphates are soluble across the $\mathrm{pH}$ range. As the leaching progresses, the leachate composition will reflect this rapid depletion of salts.

The extent to which trace elements are leached depends on the concentration in fly ash, although as a general rule there is no direct correlation. The leachability is also closely related to the concentration and mode of occurrence in the feed coal, the combustion conditions, the role of sorption/desorption, redox conditions and, most importantly, the $\mathrm{pH}$. The trace element mobility in water is heavily pH-dependent (de Groot, 1989).

The $\mathrm{pH}$ of the ash-water system seems to be controlled by the ratio between ubiquitous Ca and S concentrations in fly ash (Querol et al., 2001), although other minor alkalis or alkaline earth cations such as Mg may also contribute to the balance (Ward et al., 2009). The occurrence and levels of Ca-bearing phases in ash are intimately related to the depositional environment of coal. Based on $\mathrm{Ca} / \mathrm{S}$ balance and the $\mathrm{pH}$, fly ash can be split up in 3 main groups:

- Strongly alkaline ashes: free-lime dissolution dominates leaching, with pH values typically in the $\mathrm{pH}$ 11-13 range (van der Sloot, 1997) and large amounts of Ca in the leachates. Ca prevails over $\mathrm{S}(\mathrm{Ca} / \mathrm{S}>>1)$.

- Mildly alkaline ashes: anhydrite dissolution dominates leaching, with moderately low Ca levels and balanced $\mathrm{Ca} / \mathrm{S}$ ratios that give rise to mildly alkaline conditions ( $\mathrm{pH} \mathrm{8-9)} \mathrm{(Querol}$ et al., 2001)

- Acidic fly ash: depleted in $\mathrm{CaO}$ and $\mathrm{MgO}$ in relation to the sulphate content (Ward et al., 2009) and therefore retains its original acid characteristics, as the acidic components concentrated on the surface of fly ash particles are initially brought into solution as sulphuric acid (Swaine, 1990).

It should be borne in mind that $\mathrm{pH}$ of the ash-water system is not static but changes over time. As $\mathrm{pH}$-controlling elements migrate with water percolation, both acid and alkaline ashes tend to progressively develop more neutral $\mathrm{pH}$ values, affecting the mobility of some of the elements concerned. 
A given element may dissolve from fly ash and then precipitate as stable and less soluble secondary phases (Iyer, 2002), with the result that the element is removed from the leachates. As will be discussed later, minerals such as ettringite $\left[\mathrm{Ca}_{6} \mathrm{Al}_{2}\left(\mathrm{SO}_{4}\right)_{3}(\mathrm{OH})_{12} \cdot 26 \mathrm{H}_{2} \mathrm{O}\right]$, which is the primary phase always reported during the reaction of alkaline ash with water (Hassett et al., 2005), may capture a number of trace elements (Jones, 1995). Ettringite requires $\mathrm{Ca}, \mathrm{Al}_{1} \mathrm{SO}_{4}{ }^{2-}$, excess water and $\mathrm{pH}>11$ to form (Hassett et al., 2005). The precipitation of various Ca-bearing species is also common, given the ubiquity of $\mathrm{Ca}$. Sorption phenomena on Fe oxides are a recognised process that may reduce the mobility of elements, as the Fe oxides provide sites for metal binding. The above processes are $\mathrm{pH}$-sensitive.

\section{LEACHING PROTOCOLS AND REGULATIONS}

There is a wide range of standardised leaching tests with variable complexity, reagents, temperature, agitation method, liquid to solid ratio (L/S), contact time (among other parameters) along with some others non standardised but appropriated for specific purposes. Some of them are devised to mimic specific scenarios, some others are aimed at obtaining predictions on available concentrations and used as a surrogate for long term releases. A detailed discussion on the worldwide standard leaching tests is out of the scope of this study and can be found elsewhere (Chandler et al., 1997; Kim, 2002; van der Sloot, 1997; Zandi and Russell, 2007).

Any attempt to integrate the outcomes of such a wide range of leaching conditions must be undertaken with due care. The results obtained in absolute value cannot be directly compared, and therefore they cannot provide an accurate uniform basis for data interpretation. For this reason, the present study is not intended to be a database on leachable concentrations, but instead focuses on providing a broad view on the mobility of elements in fly ash. In order to assist in the comparison, the leachable concentrations mentioned throughout the text are reported in $\mathrm{mg} / \mathrm{kg}$ where possible. The mobility is expressed in terms of extractable proportions in weight, i.e. the ratio between the leached concentration of a given element with respect to the total concentration of that element in the fly ash.

Among the variety of available leaching procedures, four types are commonly used in the literature to assess the leaching behaviour of coal ash: (i) batch leaching tests using deionised water or similar as leachant (no $\mathrm{pH}$ buffering) are often conducted to obtain information on the leachability of elements when the $\mathrm{pH}$ is governed by the ash itself; (ii) column/flow-through tests provide valuable data on the release pattern of elements under uncontrolled $\mathrm{pH}$ conditions; (iii) Toxicity Characteristic Leaching Procedure (TCLP), designed by US EPA and 
mandated for use in determining the hazardousness of materials to be disposed of (Hassett et al., 2005). The US EPA does not specifically recommend this test for coal combustion products, as it does not provide an accurate assessment of this material (Federal Register, 2010; Hassett et al, 2005). However, the TCLP appears to be the worst case test most often used throughout the literature. The test is conducted using buffered acetic acid solutions with $\mathrm{pH}=2.88$ or $\mathrm{pH}=4.93$ depending on the $\mathrm{pH}$ of the material; (iv) acid extractions, performed under aggressive conditions $(\mathrm{pH}<2)$ that are difficult to relate to field conditions, but are aimed at gaining an in-depth knowledge of the ash chemistry.

Given that a number of elements contained in fly ash are markedly $\mathrm{pH}$ sensitive, unified curves presenting the $\mathrm{pH}$-dependent solubility of various elements are plotted where possible (Figure 1), after the compilation of data from various sources (Chandler et al., 1997; de Groot, 1989; Dubikova et al., 2006; Jankowski et al., 2004; Jones, 1995; Moreno et al., 2005; van der Sloot, 1990; Zandi and Russell, 2007). In interpreting the curves is important to bear in mind that a number of factors (e.g. presence of complexing agents such as $\mathrm{Cl}^{-}$) can shift the depicted curves or change the leaching pattern, hence this must be taken as a general trend.

\section{MAJOR ELEMENTS}

\section{ALUMINIUM}

Aluminium is poorly leached, particularly when considering its abundance in fly ash. Due to the extremely slow dissolution rates of the glassy matrix and the crystalline aluminosilicate phases (Dudas, 1981), low proportions of Al are leached whatever the leaching test applied. Ranges of leachable concentrations of over two orders of magnitude are not rare (EPRI, 1998). The leachability of $\mathrm{Al}$ is markedly dependent on the $\mathrm{pH}$ (Figure 1 ). The region of low solubility around $\mathrm{pH} 5$ to 7 (<0.1\% Al extractable from Australian and US fly ash (Kim et al., 2003; Ward et al., 2003)) is attributed to solubility constraints of amorphous $\mathrm{Al}(\mathrm{OH})_{3}$ (Fruchter et al., 1990), which is present in fly ash (Dudas, 1981). The solubility increases sharply towards $\mathrm{pH}<4$ (up to $10 \% \mathrm{Al}$ is leachable according to Kim et al. (2003)) and in the $\mathrm{pH} \mathrm{9-11} \mathrm{range.} \mathrm{In} \mathrm{alkaline}$ environments, $\mathrm{Al}$ is leached as aluminate $\mathrm{Al}(\mathrm{OH})_{4}{ }^{-}$forms. It is for this reason that, for alkaline fly ash, the leached levels of Al from water-based tests (rarely exceeding $200 \mathrm{mg} / \mathrm{kg}$, typically pH 9-12) (Baba and Kaya, 2004; Dubikova et al., 2006; EPRI, 1998; Moreno et al., 2005) are often higher than those of the TCLP (close to the detection limit in the large data set reported by EPRI, 1998). The drop in the Al leachability at $\mathrm{pH} \approx 11.5$ is consistent with that of $\mathrm{Si}$ and other oxyanions, and is directly linked to the precipitation of ettringite (Cornelis et al., 2008; Jones, 1995). 
Although some authors suggest that the hydrolysis of mullite $\left[\mathrm{Al}_{6} \mathrm{Si}_{2} \mathrm{O}_{13}\right]$ would be a major source of Al in alkaline fly ash leachates (Roy and Griffin, 1984), mullite is considered a non reactive mineral in aqueous solutions (Tishmack, 1996). The dissolution of the amorphous glassy matter appears to be the most likely source of Al in leachates (Dubikova et al., 2006; Querol et al., 2001). The structure and composition of the glass may enhance the reactivity and leachability of Al. Seidel and Zimmels (1998) found that those glasses modified with alkaline and alkaline earth elements show a more open structure that is susceptible to chemical attack and enhanced leaching.

\section{CALCIUM}

Calcium is present in fly ash in multiple modes of occurrence, primarily lime, anhydrite, calcite and within the glassy matrix. It is the most largely released cation regardless of the extractant used (Kim et al., 2003). The leachable concentrations range over several orders of magnitude as a function of the mode of Ca occurrence and concentration in the fly ash, the proportion of each phase and the leaching test performed. With only water, the amounts of Ca leached could easily fall in the 100-15000 mg/kg range (Iwashita et al., 2005; Izquierdo et al., 2011; Medina et al., 2010; Moreno et al., 2005). The water extractable proportions measured for a large set of data are in the $7-14 \%$ range (Moreno et al., 2005; Nugteren, 2010; Ward et al., 2003), where high values would indicate that $\mathrm{Ca}$ is present as free lime. The proportions mobilised under TCLP and other acidic tests are much larger (25\% according to Ward et al., 2003), as Cabearing salts are more easily dissolved. The leaching pattern depicted in Figure 2 shows how $\mathrm{Ca}$ releases drop one order of magnitude in the first stages of a column test. This quick washout of relatively soluble Ca-bearing species, e.g. Ca-sulphates, is followed by the slow release from insoluble forms such as calcite.

Calcium is not regarded as an element of concern, but it does play a primary role in the environmental quality of the ash. As discussed above, the amount of $\mathrm{Ca}$ (particularly in relation to that of $\mathrm{S}$ ) dictates the $\mathrm{pH}$ of the ash-water system, and most trace elements display a $\mathrm{pH}$ dependent solubility. As will be shown later, Ca promotes the precipitation of metalloid-bearing phases containing environmentally sensitive elements. The presence of $\mathrm{Ca}$ is also essential for the precipitation of ettringite and other secondary Ca-hydrated phases that are likely to incorporate and retain environmentally relevant elements such as $\mathrm{As}, \mathrm{Cr}$ or Se. Therefore, it can be stated that Ca controls the leachate composition for the most part, and also controls the leachability of trace contaminants to a large extent.

\section{IRON}


Iron becomes soluble at $\mathrm{pH} \leq 1.5$ (Seidel and Zimmels, 1998), but releases are of little significance in relation to the concentration in the ash. Less than $1000 \mathrm{mg} / \mathrm{kg}$ were leached at $\mathrm{pH}=1.2$ from 32 US fly ash samples (Kim et al., 2003), which represents mobilisation of $<1 \%$ of the total Fe under strongly aggressive conditions. The leachable levels sharply decrease towards slightly acidic values ( $\mathrm{pH} 3-5)$, and remain very low across the rest of the $\mathrm{pH}$ range. Any Fe in solution precipitates as amorphous oxyhydroxide in response to an increase in the $\mathrm{pH}$ values (Warren and Dudas, 1988). Negligible proportions of Fe were found to be leached from fly ash (Ward et al., 2003). Less than $10 \mathrm{mg} / \mathrm{kg}$ of $\mathrm{Fe}$ are leachable in near neutral and alkaline solutions, and concentrations in most cases are below the detection limit (Kim et al., 2003; Moreno et al., 2005). Iron in fly ash is mainly present as magnetite mixed in various proportions with hematite, although a minor proportion can be assimilated in the glassy matrix (Kukier et al., 2003). Spinel structures are highly stable and resistant to weathering, and therefore Fe, and any isomorphously substituted elements, are not easily released to the environment.

Iron oxyhydroxides are also present in fly ash (Dudas, 1981). These species are widely known to play a key role in the sorption of a number of elements of environmental concern, thus attenuating the concentrations in the leachates (Turner, 1981).

\section{MAGNESIUM}

The concentrations of $\mathrm{Mg}$ leached in water range from non detectable to less than $1000 \mathrm{mg} / \mathrm{kg}$, but commonly do not exceed $50 \mathrm{mg} / \mathrm{kg}$ (Iwashita et al., 2005; Moreno et al., 2005). Magnesium in alkaline fly ash is poorly leachable in water (<0.1\%, Ward et al., 2003), but the mobility increases up to $4 \%$ in acidic fly ash. Magnesium appears to be slightly soluble at acidic pH and insoluble in water and alkaline reagents (Kim et al., 2003). This element is enriched in the glass fraction of fly ash (Warren and Dudas, 1989), which may partly account for its low solubility. Over $\mathrm{pH} 4$, the concentrations in equilibrium with ash are $\mathrm{pH}$-independent and controlled by the carbonate and hydroxide solid phases (Jones, 1995). In a column leaching test conducted by Dudas (1981), a steady rise in soluble Mg levels of leachates was observed as Ca was progressively washed out, which was attributed to the slow dissolution and hydrolytic reactions of carbonate compounds. Other authors did not observe this Ca-linked increase in $\mathrm{Mg}$ leaching over time, but the leached levels of $\mathrm{Mg}$ remained close to the detection limit (Querol et al., 2001).

\section{PHOSPHORUS}

Phosphorus is extremely insoluble in fly ash. However, this evidence comes from very limited data available in the literature. The suite of $23 \mathrm{EU}$ fly ashes reported by Moreno et al. (2005) yielded releases $<6 \mathrm{mg} / \mathrm{kg}$ and often $<1 \mathrm{mg} / \mathrm{kg}$. The water extractable proportions in acidic and 
alkaline fly ash from Australia were estimated at $<0.5 \%$ by Ward et al. (2003). The figures for TCLP were very similar for most samples. Dudas (1981) found that $P$ remained immobile over a 2 yr-long column leaching test and concluded that this element occurs within the silicate matrix or as adsorbed constituents. However, Dubikova et al. (2006) and Jones (1995) suggested the occurrence of highly insoluble Ca-phosphates.

\section{POTASSIUM AND SODIUM}

Although $\mathrm{K}$ and $\mathrm{Na}$ in coal may be precipitated from groundwater or infiltrating hydrothermal fluids, they are more likely to be associated with feldspars and clays, which would account for their primarily silicate distribution in fly ash (Kim and Kazonich, 2004). Potassium is regarded as a measure of the glass abundance (Spears, 2004). In long term column leaching tests, initial levels of $\mathrm{Na}$ and $\mathrm{K}$ in solution are attributed to the dissolution of surface salts (Warren and Dudas, 1989), whereas further releases may correspond to the dissolution of the fly ash matrix (Dudas, 1981). Potassium and Na are tightly bound within the glassy matrix, and therefore less than $2 \%$ is available for leaching under TCLP and water-based leaching tests in both acidic and alkaline fly ash (Moreno et al., 2005; Ward et al., 2003). Any $\mathrm{K}$ and Na removed is more likely to occur in more readily leachable compounds, such as soluble Al-K-sulphate coatings absorbed on glassy particles (Rice et al., 1999). Such species are dissolved across the $\mathrm{pH}$ range and typically yield 20-2000 mg/kg leachable $\mathrm{K}$ and $\mathrm{Na}$ from alkaline fly ash (Moreno et al., 2005).

\section{SILICON}

Querol et al. (2001) concluded that glass is the main Si-bearing phase leached. Silicon is slowly released, but these authors demonstrated that the glass dissolution rate is enhanced by the presence of $\mathrm{OH}^{-}$in solution, as shown in Figure 1. Dissolved Si decreases between $\mathrm{pH} 8$ and 10, increases towards the acidic and alkaline ends of the $\mathrm{pH}$ range, and plunges at $\mathrm{pH} \approx 11.5$. When considering the total concentration in fly ash, it is apparent that $\mathrm{Si}$ is poorly leached regardless of the leaching test used. The water extractable proportions reported are invariably $<0.3 \%$ and typically $<0.05 \%$ for TCLP and water-based leaching tests (Moreno et al., 2005; Ward et al., 2003). Higher Si concentrations were measured for aged ash deposits, due to the advanced glass weathering after storage (Ward et al., 2009).

\section{SULPHUR}

Due to its dominant surface association in fly ash and the marked solubility of most sulphatebearing compounds, sulphur is the major soluble element in fly ash, along with $\mathrm{Ca}$. In environmental conditions, reduced $\mathrm{S}$ species are generally present in negligible quantities and $\mathrm{SO}_{4}{ }^{2-}$ is the dominant species (Fruchter et al., 1990). Iwashita et al. (2005) and Izquierdo et al. (2008) noted that the leached concentrations of $S$ in water are correlated to its concentration in fly ash. With water only, $40-80 \%$ of $\mathrm{SO}_{4}{ }^{2-}$ was removed from alkaline fly ash from Australia, the 
Netherlands and Spain, whereas up to $90 \%$ was removed from acidic fly ash (Nugteren et al., 2001; Querol et al., 2001; Ward et al., 2003). The leachability in terms of absolute levels varies over one order of magnitude, depending upon the nature (i.e. $\mathrm{pH}$ ) of the ash. Typical values for alkaline ash range from 700 to $15000 \mathrm{mg} / \mathrm{kg} \mathrm{SO}_{4}{ }^{2-}$ (Izquierdo et al., 2011; Moreno et al., 2005).

\section{TITANIUM}

Titanium commonly replaces $\mathrm{Si}$ in clays. Since clay minerals in coal give rise to the glassy matrix of fly ash during combustion, $\mathrm{Ti}$ is assimilated and retained within the aluminosilicate glassy matrix along with silicon. The findings of Warren and Dudas (1988) pointed to an almost exclusive partitioning of $\mathrm{Ti}$ into the internal matrix of ash particles. Although $\mathrm{Ti}$ might be expected to follow the leaching pattern of silicon, it is virtually immobile throughout the whole $\mathrm{pH}$ range. The extractable proportions for Australian alkaline and acidic-natured fly ash were $<0.01 \%$, whether the leaching test was conducted with water or with $\mathrm{pH} \approx 5$ extractant (Ward et al., 2003). Similar observations were reported for 23 EU fly ashes, with water leachable levels commonly in the $0.2-0.5 \mathrm{mg} / \mathrm{kg}$ range (Moreno et al., 2005).

\section{TRACE ELEMENTS}

\section{ANTIMONY}

Antimony in coal occurs in accessory sulphides along with pyrite (Finkelman, 1995). These compounds dissociate during combustion and liberate $\mathrm{Sb}$ as volatile species. Although one would expect $\mathrm{Sb}$ to mirror the geochemical behaviour of As and Se and primarily condense on fly ash as a soluble oxyanionic species, Kim and Kazonich (2004) noted a major association with the silicate phase. The mode of occurrence of $\mathrm{Sb}$ in fly ash is not fully understood; the concentration is usually $<10 \mathrm{mg} / \mathrm{kg}$ (Swaine, 1995), which introduces a great uncertainty. The leaching behaviour has been scarcely covered in the literature, perhaps for this same reason.

Miravet et al. (2006) observed that the extraction yields of Sb from a Spanish fly ash peaked at $\mathrm{pH} \leq 2$, while alkaline $\mathrm{pH}$ values resulted in poor extraction efficiencies. By contrast, the findings of Kim et al. (2003), based on 32 US samples, revealed that Sb is insoluble in all types of leachant. The extractable proportions ranged from 0.01 to $0.1 \%$, with the alkaline extractions falling on the high side. In another study, Kim and Kazonich (2004) showed that, despite the fact that the dominant mode of occurrence of $\mathrm{Sb}$ was the silicate fraction, the minor fraction in non-silicate association (presumably in oxyanionic form) would be responsible for the leaching of $\mathrm{Sb}$ at alkaline pH levels. Ward et al. (2003) compared results from various leaching tests on Australian fly ashes and found that $0.3-3 \% \mathrm{Sb}$ is water extractable from acidic-natured fly ash, while up to $6 \%$ can be leached from alkaline fly ash. Adsorption of Sb oxyanions on Fe oxides is 
significant from very low $\mathrm{pH}$ values to $\mathrm{pH} \approx 8$ (Cornelis et al., 2008), but under alkaline conditions, sorption processes are less effective and Sb remains in solution (Figure 1). Nevertheless, the water releases generally do not surpass $0.7 \mathrm{mg} / \mathrm{kg}$. The decline in Sb releases in the $\mathrm{pH} \approx 11.5$ region (Figure 1 ) is consistent with the uptake of $\mathrm{Sb}$ by ettringite and subsequent precipitation (Cornelis et al., 2008). Differences in the TCLP are also significant (Ward et al. (2003) reported $1-4 \%$ and $4-12 \%$ extractable from acid and alkaline ash, respectively), which suggests that the amount of $\mathrm{Ca}$ in the parent coal plays a determinant role in favouring surface-rich antimonate species in ash over silicate-associated modes of occurrence.

\section{ARSENIC}

In most coals, As is primarily associated with As-bearing pyrite (Finkelman, 1995), which is decomposed during the combustion and gives rise to a dominant surface association in the ash. Arsenic condenses on the surface of fly ash particles as sparingly soluble arsenate species (Goodarzi et al., 2008; Huggins et al., 2000b). As an oxyanionic species, As is characterised by a $\mathrm{pH}$-dependent leaching (Figure 1), and displays a plateau of maximum solubility in the $\mathrm{pH}$ 711 range. However, the leaching of this element is complex and a combination of factors needs to be taken into account to fully explain its leaching behaviour.

Arsenic has attracted considerable attention due to the fact that it is mobile throughout a wide $\mathrm{pH}$ range. The leachability varies widely depending on the nature of the fly ash. Arsenic releases from acidic fly ash increase with $\mathrm{pH}$, whereas in alkaline fly ash this trend is reversed (van der Hoek et al., 1994). The response to different leaching procedures is also notably variable. While both TCLP and water-based leaching tests conducted on Australian acidic fly ash removed 0.3$20 \%$ arsenic, a substantial difference between water leaching (0.3-15\%) and TCLP (5-30\%) on alkaline ash was noted (Ward et al., 2003). The water extractable proportions for a suite of 23 EU fly ashes were in the 0.001-25\% range (Moreno et al., 2005), while Querol et al. (2001) reported $52 \%$ extraction yields by using column tests and high L/S ratios. Arsenic solubility in water extracts of strongly alkaline fly ash is consistently low, $<0.01 \mathrm{mg} / \mathrm{kg}$ (Grisafe et al., 1988; Izquierdo et al., 2011). However, mildly alkaline ashes revealed greater releases (0.6-3 $\mathrm{mg} / \mathrm{kg}$ ).

Such variability is ascribed to adsorption processes and the interaction with other species. The role that Ca plays on the leaching of As is noteworthy. The influence is more evident when using column leaching tests, as these provide an insight into the release pattern. As depicted in Figure $2 \mathrm{a}$, in a mildly alkaline and low-Ca fly ash, As release peaks at the early stages of the test and decreases progressively with time. In the presence of notable amounts of $\mathrm{Ca}$ and alkaline $\mathrm{pH}$ (Figure $2 \mathrm{~b}$ ), the peak broadens and shifts towards higher L/S ratios. Such delayed response 
points to retention in secondary species controlling the solubility i.e. the precipitation of Caarsenate. Arsenic is not removed until Ca releases are 10 times lower and the leachate becomes understaturated in Ca-arsenate. In the case of very high-Ca fly ash (Figure 2c), the peak shifts towards even higher L/S ratios. The dissolution rates are extremely low and arsenic is slowly released. The formation of insoluble Ca-arsenate is common in Ca-rich ash (Yudovich and Ketris, 2005), whereas low-lime fly ash provides less chance for this phase to precipitate. The precipitation of ettringite at $\mathrm{pH}>11.5$ would also account for the dramatic reduction in As in solution (Figure 1), along with Al, Si, S and and other oxyanionic species (Jones, 1995; Cornelis et al., 2008). According to Hassett et al. (2005), As in its oxyanionic form is too large to fit into the ettringite structure, but it can sorb on to already-formed ettringite. At such $\mathrm{pH}$ values, portlandite may contribute to the sequestration of As by strongly sorbing arsenate (van der Hoek et al., 1994).

Mullite may be a relevant adsorbent mineral in the neutral $\mathrm{pH}$ range (van der Hoek et al., 1994), although Fe oxyhydroxides and to a lesser extent Al and Mn oxides play a major role in As scavenging from pH 3 to $\mathrm{pH} 8$ (Cornelis et al., 2008; Jones, 1995; Turner, 1981). The affinity of arsenate for metal oxides decreases above $\mathrm{pH} 8$, which leads to increased leachability (Figure 1). The co-precipitation of As with phosphates and carbonates has been also pointed out as a major sink for this element (Cornelis et al., 2008; Jones, 1995).

\section{BARIUM}

Barium in fly ash forms sparingly soluble compounds with carbonates and sulphates (Fruchter et al., 1990). The leachability does not show any significant dependence on $\mathrm{pH}$ but is rather controlled by the ubiquitous $\mathrm{Ca}$ against which it competes for suphate. The presence of large amounts of $\mathrm{Ca}$ in solution would promote the precipitation of more insoluble sulphate, more likely co-precipitated as (Ba,Sr) $\mathrm{SO}_{4}$ than as $\mathrm{BaSO}_{4}$ or $\mathrm{SrSO}_{4}$ (Fruchter et al., 1990). Particular attention should be given to $\mathrm{Ba}$ metalates, because they have low solubility products that would also attenuate Ba releases (Cornelis et al., 2008). The above features result in Ba being poorly leached throughout the $\mathrm{pH}$ range. Less than $2 \% \mathrm{Ba}$ was extracted from a large number of US fly ash samples regardless of the leachant agent considered, including $\mathrm{pH} \approx 1$ extractants (Kim et al., 2003). Little difference in terms of Ba mobility was found between TCLP and water-based leaching tests results for both alkaline and acidic-generating Australian fly ash (Ward et al., 2003). The mobility typically ranged between 0.02 and $2 \%$. The suite of EU ashes of Moreno et al. (2005) revealed $0.2-15 \mathrm{mg} / \mathrm{kg}$ of water leachable Ba.

\section{BERYLLIUM}

Although scarcely studied in the literature, it is apparent that the most important parameter limiting Be solubility from ash is the $\mathrm{pH}$ (Figure 1). Beryllium is insoluble at near-neutral and 
alkaline $\mathrm{pH}(<0.1 \%$ water extractable fractions, $<0.01 \mathrm{mg} / \mathrm{kg}$ ), but slightly mobile under acidic conditions (Dreesen et al., 1977; Kim et al., 2003; Moreno et al., 2005; Ward et al, 2003). Of 84 field leachate samples from fly ash disposal impoundments in the US, only 5 samples contained detectable Be concentrations in the 0.8-9 $\mu \mathrm{g} / \mathrm{L}$ range (EPRI, 2006), and these samples happened to have a pH lower than 6. In another study conducted by the EPRI (1998), out of 453 groundwater samples taken, 42 contained Be at concentrations higher than $4 \mu \mathrm{g} / \mathrm{L}$. The results of this investigation suggest that Be is likely to be sorbed to the solid phase under neutral and alkaline $\mathrm{pH}$. TCLP tests conducted on Australian fly ash revealed extractable proportions of $0.5 \%$ (Ward et al., 2003). The leachable rates increase with decreasing $\mathrm{pH}$ and $1.7 \%$ is mobile at $\mathrm{pH} \approx 4$ (Dreesen et al., 1977). Kim et al. (2003) measured $0.5 \mathrm{mg} / \mathrm{kg}$ of leachable $\mathrm{Be}$ at $\mathrm{pH}<3$. The extractable fraction reaches $12 \%$ when the $\mathrm{pH}$ is adjusted at 0.6 using strongly acid extractants (Dreesen et al., 1977).

\section{BORON}

The mode of occurrence of this element in coal was found to strongly influence the mobility in fly ash. The pronounced leachability of $B$ is intimately related to its dominant surface association in fly ash (Querol et al., 1995). Most of the B is organically associated in coal (Swaine, 1995; Finkelman, 1995). Such affinity enhances the volatility during combustion and the subsequent condensation of soluble admixed borate salts onto fly ash (Dudas, 1981). However, in some coals, B occurs in illite or in the highly refractory tourmaline (Querol et al., 1997a and b), with the result that it is not leached, as Boyd (2002) noted. Boyd (2002) pointed out that the aforementioned silicate structures can lock B up during ashing at $1000^{\circ} \mathrm{C}$. Moreover, James et al. (1982) observed some thermal fixation mechanisms on fly ashes produced at higher temperatures, with the result that B mobility was attenuated.

Early studies pointed out that a large fraction of B in fly ash is in soluble form (Cox et al., 1978; James et al., 1982). It is one of the elements most readily released from fly ash in water. A 15min contact of fly ash with water was sufficient to leach most of the soluble B from ash (Cox et al., 1978). The findings of Querol et al. (2001) also support the fact that this element is susceptible to quick leaching, despite the high ionic loads in initial leachates (Figure 2).

The water extractable yields in the literature are invariably high, typically ranging from 17 to 65\% (Cox et al., 1978; James et al., 1982; Sear et al., 2003; Ward et al., 2003). These researchers underline $B$ as the most mobile trace element in coal ash. There is no substantial difference between acidic and alkaline ash, since B leachability does not depend significantly upon $\mathrm{pH}$ over pH 6 (Cox et al., 1978). Rather, the leached levels appear to be controlled by the total concentration in the fly ash (Iwashita et al., 2005). The lower concentrations of B under mildly acidic conditions may be attributed to ligand exchange mechanisms (Jankowski et al., 
2004), although much greater leaching rates are achieved when under strongly acidic conditions (Dreesen et al., 1977).

Early studies brought to light the likelihood for ettringite to incorporate B within its mineral lattice, thereby decreasing in the dissolved concentrations at $\mathrm{pH} \approx 11.5$ (Hassett et al., 2005). The co-precipitation of $\mathrm{B}$ with $\mathrm{CaCO}_{3}$ under alkaline conditions has been also reported to significantly capture B in alkaline fly ash (Iwashita et al., 2005), but this process is unlikely to occur in acidic-natured fly ash (Jankowski et al., 2006).

\section{CADMIUM}

The environmental concerns over $\mathrm{Cd}$ arise from its potential solubility and toxicity in aquatic systems. Fly ash is, however, depleted in Cd in comparison with other trace elements (except $\mathrm{Hg}$ ), and this environmentally sensitive element is consistently immobile in near neutral and alkaline conditions. Despite its association with the surface of fly ash particles, the concentrations leached in water rarely surpass $0.01 \mathrm{mg} / \mathrm{kg}$ in alkaline natured fly ash (Fruchter et al., 1990; Medina et al., 2010; Moreno et al., 2005; Nathan et al., 1999) while values for acidic fly ash from Australia equate to $0.1 \mathrm{mg} / \mathrm{kg}$ at $\mathrm{pH} \approx 4$ (Jankowski et al., 2004; Ward et al., 2009). Figure 1 provides an insight into the response of $\mathrm{Cd}$ to the $\mathrm{pH}$. Cadmium is somewhat leached under acidic conditions but yet poorly extracted. Less than $10 \% \mathrm{Cd}$ in ash was removed from US alkaline fly ash at a pH of 1 (Kim et al., 2003), while 3-9\% was extracted at a pH of 4 from acidic-natured Australian fly ash (Jankowski et al., 2004). The solubility decreases towards near-neutral conditions (which results in detectable concentrations under TCLP conditions); Cd remains virtually immobile across the $\mathrm{pH}$ range over 7 , although some authors have noted a mild amphoteric behaviour (Figure 1).

Of particular note is the effect of $\mathrm{Cl}$ on the leaching pattern of $\mathrm{Cd}$. High chloride contents may shift the $\mathrm{Cd}$ solubility curve to higher $\mathrm{pH}$ values as a result of complexation processes that enhance the mobility (Jones, 1995).

\section{CHROMIUM}

A number of studies have been devoted to resolving the $\mathrm{Cr}$ speciation in coal and fly ash, since the different oxidation states pose different threats to the environment. Chromium in its hexavalent oxidation state, which includes chromates or dichromates, is widely recognised as potentially carcinogenic and highly soluble in aqueous media (Huggins and Huffman, 2004), whereas trivalent $\mathrm{Cr}$ (III) is less soluble and of much less concern to human health.

Chromium appears to occur in most bituminous coals as $\mathrm{Cr}^{3+}$ in organic association and primarily as $\mathrm{Cr}^{3+}$ in illite (Goodarzi et al., 2008; Huggins and Huffman, 2004; Huggins et al., 
2000a; Ruppert et al., 1996), whereas there is little evidence for the presence of $\mathrm{Cr}^{6+}$ (Huggins et al., 1999). The occurrence in illite gives rise to an aluminosilicate association (primarily in glass) in fly ash, remaining as $\mathrm{Cr}^{3+}$ (Goodarzi et al., 2008; Spears, 2004; Spears and MartinezTarrazona, 2004). Under such conditions, $\mathrm{Cr}$ behaves like other trace metal cation discussed, and would be leachable only under non-environmental conditions, i.e. very low pH values and reducing conditions. Some coal basins close to ultramafic bodies are known to be anomalously enriched in $\mathrm{Cr}^{3+}$, essentially in refractory and highly insoluble chromites and Cr-rich-spinel minerals (Foscolos et al., 1989; Izquierdo et al., 2011; Ruppert et al., 1996). Moreover, $\mathrm{Cr}^{6+}$ in coal is easily reduced in flue gases by $\mathrm{SO}_{2}$, and thus the dominant speciation in ash is $\mathrm{Cr}^{3+}$ (Huggins et al., 1999, 2000). Several authors have estimated the fraction of $\mathrm{Cr}^{+6}$ oxidation state in fly ash at <5\% (Goodarzi et al., 2008; Huggins et al., 1999).

Most data in the literature reflects such predominant $\mathrm{Cr}^{3+}$ speciation. Leaching tests on acidic fly ashes from Australia hardly mobilised any $\mathrm{Cr}$ (0.03\%) (Dubikova et al.,2006). Dubikova et al. (2006) also reported slightly higher mobilities for alkaline ash and increasing releases with increasing $\mathrm{pH}$. The leaching pattern of $\mathrm{Cr}$ displays a marked $\mathrm{pH}$ dependence, reaching the lowest values at near-neutral $\mathrm{pH}(0.02 \mathrm{mg} / \mathrm{kg})$ and showing a leachability plateau from $\mathrm{pH} 8$ to 12 (typically around $5 \mathrm{mg} / \mathrm{kg}$ ) (Figure 1 ). In terms of mobility, these experiments indicate water extractable proportions of 1-4\%, peaking at higher $\mathrm{pH}$ values. The findings of other researchers fall within this narrow range as long as water is used (Baba and Kaya, 2004; Kim and Hesbach, 2009), although column tests yield higher cumulative releases ( $8 \%$ according to Querol et al., 2001). Soco and Kalembkiewicz (2009) concluded that $8.2 \%$ of the total $\mathrm{Cr}$ can be leached from a Polish fly ash in environmental conditions. Under alkaline and oxidising conditions, any soluble $\mathrm{Cr}$ is likely to occur in chromate form. The high sulphate concentrations in conjunction with alkaline $\mathrm{pH}$ depress adsorption processes (Fruchter, 1990). In contrast to As, large amounts of $\mathrm{Ca}$ in solution do not prevent the readily soluble chromates from being dissolved (Figure 2). Figure 1 reflects the affinity of ettringite for $\mathrm{CrO}_{4}{ }^{2-}$ and how the precipitation of this compound contributes to scavenge this element (Cornelis et al., 2008).

Few fly ashes show water leachability of $\mathrm{Cr}$ reaching $20 \mathrm{mg} / \mathrm{kg}$ (Izquierdo et al., 2011). Certain fly ash samples exhibit up to $20 \% \mathrm{Cr}$ as $\mathrm{Cr}^{6+}$ (Huggins et al., 1999). The presence of oxygenrich organic matter in coal may lead to a higher percentage of chromates being formed during combustion. Moreover, the different leaching behaviour could also be due to the depositional settings of the original peat-forming environments. $\mathrm{Cr}^{3+}$ leached out from weathered ultramafic bodies could reach lignite beds in aqueous form, as reported for $\mathrm{Ni}^{2+}$ (Foscolos et al., 1989; Ruppert et al., 1996), and remain organically associated. The organic bonds enhance $\mathrm{Cr}$ volatilization during combustion, oxidation and precipitation of soluble chromates on fly ash. 


\section{CESIUM}

In the column experiments conducted by Querol et al. (2001), Cs revealed a quick dissolution in the earliest stages $(0.003 \mathrm{mg} / \mathrm{kg}$ for a L/S ratio=5 L/ kg), followed by a sharp decrease thereafter $(<0.1 \mu \mathrm{g} / \mathrm{L})$. This leaching pattern points to a quick washout of readily soluble salts. Warren and Dudas (1988) suggested that Cs is primarily associated with the less soluble internal matrix of fly ash particles. Thus, Cs would be released through a process of solid state migration, similar to the process that occurs in other glassy materials. Such a slow dissolution process would account for very low water extractable yields and water releases typically of 0.02 $\mathrm{mg} / \mathrm{kg}$ for EU fly ash (Moreno et al., 2005). High Ca fly ash may display higher leachable concentrations of Cs $(0.2 \mathrm{mg} / \mathrm{kg})$, due to enrichment in readily soluble alkali metal-bearing salts, primarily sulphates (Izquierdo et al., 2011).

\section{COBALT}

Hansen et al. (1981) stated that the mode of occurrence of $\mathrm{Co}, \mathrm{Ni}$ and $\mathrm{Mn}$ in ash is more dependent on similarities in the ionic radii than on the chalcophilic or lithophilic nature of the elements. Such similarities would favour their crystallization from the melt into Fe oxides. A primary association with Fe-bearing species (e.g. spinel-like structures) would explain why Co is poorly leached under slightly acidic, near neutral and alkaline conditions in relation to the total content (Figure 1). Kukier et al. (2003) found minor association of Co with the non-magnetic fraction of fly ash, and observed that such Co was much more mobile than that contained in the magnetic fraction, particularly under acidic conditions. This gives support to the idea that the solubility of an element is not always related to the dominant phase (Kim and Kazonich, 2004).

Water releases of Co for EU fly ash are typically $0.02 \mathrm{mg} / \mathrm{kg}$ (Moreno et al., 2005). Data from the suite of ashes of Jankowski et al. (2004) and Moreno et al. (2005) revealed minimum Co leachability attained at pH 9-10 and a 10-fold increase in Co leachability towards pH 12 (Figure 1 ), giving rise to an amphoteric $U$-shaped solubility curve. In the extensive data set reported by EPRI (1998) on US fly ash, all of the results from synthetic precipitation leaching procedures were non-detects for Co but only $25 \%$ of the TCLP results were non-detect. The fraction of Co available for leaching under TCLP conditions $(\mathrm{pH} \approx 5)$ is estimated at $1.5-2.5 \%$ (Ward et al., 2003). Greater amounts of this element are leached with decreasing pH (Figure 1), and up to $5 \%$ Co can be extracted at $\mathrm{pH} \approx 1$ (Kim et al., 2003).

\section{COPPER}

About $2-5 \%$ of the total $\mathrm{Cu}$ is leached at $\mathrm{pH} \approx 3$ from both the magnetic and non-magnetic fraction of fly ash samples from the US (Kukier et al., 2003). This observation, in conjunction with the small difference between the solubility of the two fractions, suggests that Cu shows 
some degree of mobility in an acidic environment, regardless of the mode of occurrence. Querol et al. (1996) noted a markedly variable mobility as a function of the mode of occurrence in the parent coal. A dominant association with clay minerals in coal results in a primary glass association in fly ash, which in UK fly ash can be up to 60\% (Spears, 2004). Copper is therefore assimilated within the glass and not easily released. In contrast, the oxidation of $\mathrm{Cu}-\mathrm{Fe}-$ sulphides in coal leads to a higher mobility of $\mathrm{Cu}$ in fly ash.

The mobile fraction of $\mathrm{Cu}$ in environmental conditions has been estimated at $2.6 \%$ (Soco and Kalembkiewicz, 2007). TCLP results yielded $0.5-3 \% \mathrm{Cu}$ extractable for alkaline fly ash (Ward et al., 2003). However, $\mathrm{Cu}$ was leached to a much greater degree in acidic extractants, as the releases increased by a few orders of magnitude (Figure 1 ). The mobility at $\mathrm{pH} \approx 1$ attained $8 \%$ (Dreesen et al., 1977; Kim et al., 2003). The releases plunged over two orders of magnitude towards near neutral to alkaline conditions (Figure 1 ). Typically $0.05-0.1 \% \mathrm{Cu}$ is removed by water leaching of alkaline fly ash (Moreno et al., 2005; Ward et al., 2003), which in terms of releases would be around $0.05 \mathrm{mg} / \mathrm{kg}$. These values may increase in acid-generating fly ash (Figure 1). The results of Jankowski et al. (2004) and Chandler et al. (1997) indicate that Cu would be mildly amphoteric (Figure 1), although data from other surveys in the literature do not follow this trend and remain at very low levels at pH 12 (Izquierdo et al., 2011; Moreno et al., 2005; Ugurlu, 2004).

\section{FLUORINE}

Fluorine is almost completely vaporised during combustion (Meij, 1995) and it is mostly present in the vapour phase, while only minor proportions condense on fly ash. Piekos and Paslawska (1998) demonstrated that the leaching of fluorides from Polish coal ash is independent of temperature, and increases with the decreasing particle size of ash. Their findings suggest that $F$ in ash occurs in sparingly soluble salts embedded in surfaces of glass particles formed at low temperatures in the stack.

Around $60 \mathrm{mg} / \mathrm{kg} \mathrm{F}$ are leachable in water at a high L/S ratio $(100 \mathrm{~L} / \mathrm{kg}$ ) (Piekos and Paslawska, 1998), while other authors have reported water releases in the $5-25 \mathrm{mg} / \mathrm{kg}$ range for $\mathrm{L} / \mathrm{S}=10$ L/kg (ABETRAP, 2009; Álvarez-Ayuso and Querol, 2008; Dreesen et al., 1977). In all cases, the levels suggest that $F$ leaching is not of great concern in fly ash.

Fluorine appears to have a marked pH-dependent solubility, but the dearth of published data on fluoride leaching from ash does not allow the authors to confidently draw a leaching curve vs $\mathrm{pH}$. Piekos and Paslawska (1998) did report a remarkable increase in the $\mathrm{F}^{-}$level in a strongly acidic medium below pH 2.5. The study of Dreesen et al. (1977) indicates that fluorine releases peak in the $\mathrm{pH}=4$ region, achieving extractable proportions of $85 \%$ of the total $\mathrm{F}$ content, and 
decrease towards the two ends of the $\mathrm{pH}$ range. At $\mathrm{pH}<1$ the extractable $\mathrm{F}$ was estimated at 70\% (Dreesen et al., 1977), while the fraction leachable in water for alkaline ash is lower and generally in the 5-10\% range (ABETRAP, 2009; Dreesen et al., 1977). According to ÁlvarezAyuso and Querol (2008), high pH depresses $\mathrm{F}$ sorption on non-crystalline alumina present in fly ash.

\section{LEAD}

Being an element associated with sulphides in coal, a marked surface association of $\mathrm{Pb}$ in ash might be expected. Around $50-60 \% \mathrm{~Pb}$ is estimated to be in surface association in fly ash (Spears and Martinez-Tarrazona, 2004), although the findings of Warren and Dudas (1988) suggest that the majority of $\mathrm{Pb}$ is probably associated with the internal glassy matrix of fly ash, and is therefore not readily leached even under extended acidic weathering. Kim and Kazonich (2004) also reported a dominant silicate association. Pb was found to be highly insoluble and virtually immobile $(<1 \%$ and often $<0.1 \%$ ) in both acidic and alkaline-natured fly ash samples, irrespective of the $\mathrm{pH}$ and the leaching test (Kim et al., 2003; Moreno et al., 2005; Nathan et al., 1999; Praharaj et al., 2002; Ward et al., 2003).

As with other cations, acidic conditions slightly enhance Pb leaching (Jones, 1995). However, the leachable concentrations remain at very low levels. Less than $1 \mathrm{mg} / \mathrm{kg}$ of $\mathrm{Pb}$ was released from US fly ash using a range of extractants and tests (Kim and Hesbach, 2009; Kim et al., 2003). Of all the experiments, it is worth mentioning that only $0.4 \mathrm{mg} / \mathrm{kg}$ of $\mathrm{Pb}$ were leached using $\mathrm{pH}=1.2$ leachant. According to Dubikova et al. (2006), the mobility of $\mathrm{Pb}$ appears to be controlled by the precipitation of phosphate minerals, which are highly insoluble over a wide $\mathrm{pH}$ range.

As an amphoteric metal, the solubility of $\mathrm{Pb}$ is thought to decline to a minimum around $\mathrm{pH}$ 9, and thereafter to show a marked increase at $\mathrm{pH}>11.5$ (Figure 1 ) as a result of the formation of more soluble anionic hydroxo complexes (Jones, 1995). However, a number of studies are not consistent with this leaching pattern. Out of the over 30 fly ashes with pH 11-13 reported by Dubikova et al. (2006), Izquierdo et al. (2011), Moreno et al. (2005), Nathan et al. (1999) and Ward et al. (2003), no sample showed leached levels of $\mathrm{Pb}$ exceeding $0.06 \mathrm{mg} / \mathrm{kg}$. Given that $\mathrm{Pb}$ metalates have low solubility products, their precipitation under alkaline conditions may attenuate the leaching of $\mathrm{Pb}$ (Cornelis et al., 2008) and alter its predicted amphoteric nature. Lead was not leached during a 2 yr long column test (Dudas, 1981). In another column leaching test, Querol et al. (2001) did not find any delayed releases. These findings, in conjunction with the observed low solubility of this element throughout the $\mathrm{pH}$ range, provide evidence that $\mathrm{Pb}$ leaching does not pose a risk to the environment regardless of the total content in fly ash. 


\section{MANGANESE}

Manganese is likely associated with ferromagnetic particles and/or the glass fraction in ash (Kim and Kazonich, 2004; Warren and Dudas, 1988). Although Mn in the the glass was found to be more soluble than that contained in the magnetic fraction (Kukier et al., 2003), both modes of occurrence would be responsible for the extremely low leaching rates that Querol et al. (2001) determined. The leaching behaviour is similar to other metals; $\mathrm{Mn}$ is insoluble under near neutral to alkaline conditions, the leached levels are typically $<0.1 \mathrm{mg} / \mathrm{kg}$. Dissolved $\mathrm{Mn}$ increases with the decreasing $\mathrm{pH}$. About $25 \mathrm{mg} / \mathrm{kg}$ were leached using extractants with $\mathrm{pH} \mathrm{1-3,}$ which in terms of mobility it represents $10 \%$ of the total Mn (Kim et al., 2003).

\section{MERCURY}

Irrespective of what form of $\mathrm{Hg}$ is present in the coal, the extremely volatile elemental $\mathrm{Hg}$ is released during combustion. Chlorine and $\mathrm{S}$ in fly ash are two main elements that play a major role in the sorption of mercury in fly ash (Meij, 1995). The condensation of $\mathrm{Hg}$ on fly ash particles as the water soluble form $\mathrm{HgCl}_{2}$ may pose a risk for of contaminating groundwater. However, of particular note is the low or non detectable concentrations of $\mathrm{Hg}$ leached by TCLP or water based procedures for a large number of Australian and American fly ash samples (EPRI, 1998; Jones, 1995; Pflughoeft-Hassett, 2004). The concentrations of $\mathrm{Hg}$ in leachates are extremely low, in most cases $<0.2 \mu \mathrm{g} / \mathrm{L}$ (often $<0.02 \mu \mathrm{g} / \mathrm{L}$ ), across the $4.5-13 \mathrm{pH}$ range and show no pH dependence (Nathan et al., 1999; Pflughoeft-Hassett, 2004, Sanchez et al., 2006). Due to the toxicity of this element, small releases would trigger a regulatory response. However, the levels reported in the literature suggest that $\mathrm{Hg}$ leaching is not of major environmental concern in coal fly ash. There is a consistent lack of correlation between the total $\mathrm{Hg}$ concentration and leachable $\mathrm{Hg}$, and no significant difference as a function of the L/S ratio or between short- and long-term leaching procedures (Pflughoeft-Hassett, 2004; Sanchez et al., 2006). Mercury leaching appears to be controlled by adsorption from the aqueous phase, with strong interaction between adsorbed $\mathrm{Hg}$ molecules (Sanchez et al., 2006).

\section{MOLYBDENUM}

Molybdenum is essentially concentrated on the surface of fly ash particles (Querol et al., 1995). Spears and Martinez-Tarrazona (2004) estimated the surface association at $80 \%$ for UK fly ash. Molybdenym in this mode of occurrence is 3 times more soluble than that associated with the magnetic fraction of fly ash (Kukier et al., 2003).

The leaching behaviour of Mo is characterised by a fairly constant release in the $\mathrm{pH}$ range 7-12 (Figure 1) and a weak decrease at $\mathrm{pH} 11.5$, ascribed to a minor incorporation into ettringite structures. In comparison with other oxyanions discussed, the uptake of $\mathrm{MoO}_{4}{ }^{2-}$ by ettringite is lower due to its larger size (Kumarathasan et al., 1990). Molybdenum shows a significant 
reduction in solubility below pH 5 (Ward et al., 2009), and therefore it should be of less concern in acidic fly ash. This is likely caused by increased sorption on Fe oxyhydroxides (maximum at $\mathrm{pH} 3$ to 4 ) and $\mathrm{Al}$ oxyhydroxides ( $\mathrm{pH}$ range 4-5) (Jones, 1995).

Water extractable yields for alkaline ash consistently ranged between 15-50\% (Dreesen et al., 1977; Izquierdo et al., 2011; Nugteren et al., 2001; Ward, 2003), but high L/S ratios removed nearly $70 \%$ Mo (Querol et al., 2001). The findings of these authors show that Mo is readily leachable regardless of the concentration of $\mathrm{Ca}$ in the leachates (Figure 2), which provides a clue as to the high solubility of Ca-molybdates. The water releases of a suite of ashes studied by Moreno et al. (2005) revealed levels in the $2-7 \mathrm{mg} / \mathrm{kg}$ range. Over $30 \mathrm{mg} / \mathrm{kg}$ leachable Mo were measured in a lignite fly ash, due to an anomalous enrichment of this element in the parent coal (Izquierdo et al., 2011). With the above in mind, it can be stated that Mo is a pollutant of real concern in alkaline fly ash.

Because of its mobility, Mo is regarded as a good indicator as to the potential of coal ash leachate to contaminate groundwater (Hjelmar, 1990). It is worth mentioning that care should be taken when addressing the potential leachability of this element. Hassett et al. (2005) pointed out that the TCLP underestimates Mo leachability in alkaline fly ash, since this element leaches more in deionized water than in mildly acidic conditions. Consequently, the TCLP is not the worst-case approach for leaching assessment of Mo.

\section{NICKEL}

There is much evidence to link this element with organic constituents (Finkelman, 1995), although a variety of modes of occurrence in coal have been reported. Nickel was mostly found in oxide form in Canadian coal (Goodarzi et al., 2008), and Ni-bearing minerals (spinels and illites) are common in coalfields close to ultramafic bodies (Ruppert et al., 1996), whilst sulphide minerals containing $\mathrm{Ni}$ have been also reported (Finkelman, 1995). Whatever the association in coal, $\mathrm{Ni}$ seems to be distributed between the silicate fraction and the magnetic fraction of fly ash during combustion. While some authors found that Ni was slightly enriched in the magnetic fraction (magnetic fraction/non-magnetic ratio=1.8) (Hower et al., 1999; Kukier et al., 2003), the observations of Kim and Kazonich (2004) pointed to an enrichment in the silicate fraction. All these studies agreed that much of the leachable $\mathrm{Ni}$ is solubilised from the non-magnetic fraction.

The solubility of $\mathrm{Ni}$ is markedly sensitive to $\mathrm{pH}$ and covers a few orders of magnitude (Figure 1). Up to $10 \%$ Ni was removed when using $\mathrm{pH} \approx 1$ leachant (Kim et al., 2003). The mobility sharply decreased to $1 \%$ towards mildly acidic conditions, such as those of the TCLP on alkaline and acidic fly ash and water-based leaching tests on acidic-natured fly ash (Ward et al., 2003). 
These authors have pointed out a few exceptions to the above, which could be related to different modes of occurrence. The lowest leachable levels of $\mathrm{Ni}$ are attained in the $\mathrm{pH} 8-10$ region $(<0.05 \mathrm{mg} / \mathrm{kg}$ and $<0.01 \%$ extractable), and releases rise up to $0.2 \mathrm{mg} / \mathrm{kg}$ with increasing $\mathrm{pH}$, providing evidence of the amphoteric behaviour.

\section{RARE EARTH ELEMENTS}

The findings of Warren and Dudas (1989) indicate that rare earth elements (REE) are mostly contained in the glass phase of fly ash, with smaller amounts occurring in the ferromagnetic fraction. Both modes of occurrence result in REE being strongly bound to fly ash and therefore being poorly released. For this reason it is likely that REE leachability is overlooked in the literature. Leachable concentrations $<0.008 \mathrm{mg} / \mathrm{kg}$ for individual REE have been reported (Izquierdo et al., 2011; Querol et al., 2001), whilst Ribeiro et al. (2001) determined leachable levels of $\Sigma$ REE up to $0.17 \mathrm{mg} / \mathrm{kg}$. Georgakopoulos et al. (2002) measured water extractable proportions of individual REE in the $<0.01-0.08 \%$ range for high Ca Greek lignites, while REE in mildly alkaline Brazilian fly ash were more mobile 0.4-16\% (Pires and Querol, 2004). These observations would be in line with Warren and Dudas (1988), who found precipitation reactions in response to increases in the $\mathrm{pH}$. However, the extremely low levels leached introduce a substantial uncertainty in the estimation of the percent extractable.

\section{RUBIDIUM}

Rubidium behaves much in the same way as Cs and $\mathrm{K}$. Water leachable concentrations for EU fly ash at a $\mathrm{L} / \mathrm{S}=10$ are consistently about $0.5 \mathrm{mg} / \mathrm{kg}$ (Moreno et al., 2005). Values up to 2 $\mathrm{mg} / \mathrm{kg}$ were reported for high-Ca and sulphate-rich fly ash (Izquierdo et al., 2011). The leaching pattern obtained from column tests (Querol et al., 2001) is typical of the rapid release and depletion of highly soluble species (presumably sulphates and chlorides), even at low L/S ratio. Any delayed release would be consistent with an association with the less soluble internal matrix of fly ash, as the removal requires slow solid state migration processes (Warren and Dudas, 1988).

\section{SELENIUM}

Selenium is the most strongly enriched element in coal with respect to many rocks, and therefore coal combustion products can be regarded as a major source of this element (Dubikova et al., 2006). The main modes of occurrence of Se in coal are sulphide and organic associations, the latter being dominant in low sulphur coals (Finkelman, 1995; Yudovich and Ketris, 2006). Selenium can occur as sorbed selenate in oxidized coals (Yudovich and Ketris, 2006) and also be bonded to Fe oxides (Riley et al., 2007). Whether it occurs in pyrite or is organically associated, such weak bonding allows Se to be easily released and almost completely volatilised during combustion. Irrespective of its mode of occurrence in the coal 
matrix, Se might react with $\mathrm{Ca}$ and form stable compounds such as $\mathrm{CaSeO}_{3}$ (Shah et al., 2008) condensing on the surface of ash particles. Moreover, the selenate oxyanion resembles sulphate in structure and charge, and forms a partial solid solution $\left(\mathrm{CaSeO}_{4}-\mathrm{CaSO}_{4}\right) \cdot 2 \mathrm{H}_{2} \mathrm{O}$ (Freyer and Voigt, 2003).

$\mathrm{Se}^{4+}$ appears to be the dominant species in fly ash and its leachates (Cornelis et al., 2008; Iwashita et al., 2005; Shah et al., 2008; van der Hoek et al., 1994). Selenite and selenate compounds are relatively mobile, and display a higher solubility compared to other metalates (Cornelis et al., 2008). With water only, $10-50 \%$ of Se has been found to be extractable from a large number of fly ash samples worldwide (Iwashita et al., 2005; Nugteren et al., 2001; Ward et al., 2003).

Selenium shows a complex $\mathrm{pH}$-dependent leaching behaviour. When the $\mathrm{pH}$ is less than 2.5, the dominant species is neutral $\mathrm{H}_{2} \mathrm{SeO}_{3}$, which is not easily adsorbed on the ash surface but remains in solution (EPRI, 2008b). Over $70 \%$ of Se can be removed at $\mathrm{pH}<1$ (Dreesen et al., 1977), due to its primary surface association. As $\mathrm{pH}$ increases, the dominating anionic species $\mathrm{HSeO}_{3}{ }^{-}$and $\mathrm{SeO}_{3}{ }^{2-}$ can be adsorbed on to the ash surface and removed from leachates (EPRI, 2008b; Otero-Rey et al., 2005) (Figure 1). Aluminium and, more importantly, Fe oxyhydroxides are ubiquitous in combustion by-products and show a strong affinity to sorb selenates (Cornelis et al., 2008; Iwashita et al., 2005; Otero-Rey et al., 2005). Maximum sorption is reached in the near neutral pH region (van der Hoek et al., 1994), and sorption decreases with increasing $\mathrm{pH}$ (EPRI, 2008b). This explains why the Se mobility in acidic fly ash is generally lower than that in alkaline ash (Ward et al., 2003). This leaching pattern may have serious implications for the TCLP, often used for regulation purposes, as the TCLP is performed under the $\mathrm{pH}$ at which sorption processes are enhanced and most effective, with the result that Se releases from alkaline fly ash may be underestimated.

The solubility of Se peaks in the $\mathrm{pH} 10-12$ region and often results in water releases $\geq 1 \mathrm{mg} / \mathrm{kg}$ (Moreno et al., 2005). This strengthens Se as an element of major concern in ash due to its mobility. Selenates are assumed to be the most stable form in alkaline leachates (Jones, 1995); they are known to participate in the formation of ettringite (Cornelis et al., 2008; Hassett et al., 2005), which would account for the drop in Se releases at $\mathrm{pH} \approx 11.5$.

\section{THALLIUM}

Little data on Tl leaching are published. In an extensive report focused on this element (EPRI, 2008a), the detected concentrations were consistently low (generally $<1 \mu \mathrm{g} / \mathrm{L}$ ) and in many cases below the detection limit. EPRI (2008a) suggests that the coal rank plays a role in the leaching, since $\mathrm{TI}$ levels are generally higher at bituminous coal ash sites compared to 
subbituminous coal ash sites. The leached concentrations seem to peak at near-neutral or extreme low $\mathrm{pH}$, suggesting multiple controls. Water releases for alkaline EU fly ash were in most cases 0.001-0.005 mg/kg (Moreno et al., 2005).

\section{THORIUM}

Thorium is primarily associated with minerals in coal (Finkelman, 1995), and therefore typically occurs in the glassy matrix of fly ash. Warren and Dudas (1988) estimated that $50-80 \%$ of the total Th is in the less soluble phase in fly ash. The same authors suggest that Th is likely to be adsorbed or co-precipitated by oxhydroxides. This results in Th being poorly leached, e.g. 0.007-0.018 mg/kg from EU alkaline fly ash (Moreno et al., 2005).

\section{TIN}

Little data on tin leachability are available in the literature. The leached Sn levels in water for EU alkaline fly ash varied over a narrow range $(0.005-0.009 \mathrm{mg} / \mathrm{kg})$. Less than $0.05 \% \mathrm{Sn}$ is removed with water from Australian alkaline ash (Ward et al., 2003). The fact that the TCLP yielded similar extractable proportions supports the fact that $\mathrm{Sn}$ is extremely immobile under environmental conditions.

\section{TUNGSTEN}

Tungsten is relatively non-volatile, and its hexavalent state is thermodynamically very stable in ash and its leachates (Cornelis et al., 2008). Soluble scheelite $\left(\mathrm{CaWO}_{4}\right)$ has been detected in coal fly ash (Vassilev and Vassileva, 1996). Tungsten is immobile below pH 5 and hence TCLP and water leachability of acidic fly ash yield $<1 \%$ removable (Ward et al., 2003). As the $\mathrm{pH}$ increases, the solubility increases two orders of magnitude and reaches a leachability plateau in the $\mathrm{pH}$ 8-11 region (Figure 1 ). Thus, greater amounts of $\mathrm{W}$ can be leached from alkaline ash. Water extractable proportions fall in the $7-24 \%$, whereas the TCLP only removes up to $2 \%$ (Izquierdo et al., 2011; Ward, 2003). This behaviour mirrors Mo, and brings to light the fact that TCLP test may not always resemble the worst case leaching scenario and therefore may not provide predictions on the safe side.

\section{URANIUM}

Based on the leaching behaviour of $U$ in a Canadian fly ash, Warren and Dudas (1988) estimated that this element was partitioned approximately equally between the readily soluble and relatively insoluble phases of the ash particles. A surface association was also important in UK fly ash (Spears, 2004). Querol et al. (1996) found that $U$ in fly ash is readily exchangeable, but not water soluble. Little $U$ was released from EU fly ash with water (typically $0.005 \mathrm{mg} / \mathrm{kg}$, Moreno et al., 2005). However, given the limited data set available in the literature, we cannot 
state with confidence that these examples are typical leachable values. Some uranyl-bearing phases could be controlling the leaching under acidic $\mathrm{pH}$ conditions, while the solubility of carbonate complexes of $U$ could increase with $\mathrm{pH}$ (Warren and Dudas, 1988). The techniques used in the literature did not allow $U$ speciation to be resolved.

\section{VANADIUM}

Vanadium may occur both in clay minerals and in the easily volatilized organic matter in coal (Finkelman, 1995). This mode of occurrence results in $V$ having a surface association in fly ash, concentrated in glass or contained in magnetite to a lesser extent as a function of the distribution in the parent coal. Glass seems to be the major source of $V$ in fly ash (Spears and Martinez-Tarrazona, 2004).

Calcium vanadates are important in the context of solubility control of V (Cornelis et al., 2008). The release pattern in Figure $2 a$ shows how $V$ is readily leachable from a low-Ca fly ash. However, increasing amounts of $\mathrm{Ca}$ in solution (Figure $2 \mathrm{~b}$ and $2 \mathrm{c}$ ) slightly delay the release of $\mathrm{V}$ until the soluble fraction of $\mathrm{Ca}$ is depleted and the leachate is undersaturated with respect to Ca-vanadate. Such precipitation processes would remove $V$ from the leachates in highly alkaline fly ash and account for the low releases at strongly alkaline $\mathrm{pH}$ values (Figure 1 ). The formation of ettringite also contributes to the $\mathrm{V}$ scavenging, given that the uptake of vanadate can be significant despite the large size of this oxyanion (Kumarathasan et al., 1990).

Around $0.1-4 \% \mathrm{~V}$ is water leachable from alkaline fly ash, while $\mathrm{V}$ is less mobile $(0.2-0.5 \%)$ in acidic fly ash (Moreno et al., 2005; Ward et al., 2003). This trend reflects the lower leachability under near neutral conditions (Figure 1).

\section{ZINC}

The findings of Querol et al. (1996) underline the fact that the mode of occurrence in coal plays a critical role in the behaviour of $\mathrm{Zn}$ in ash. Querol et al. (1996) attributed high Zn mobilities in ash to the fact that much of the $\mathrm{Zn}$ was in sulphide association in the parent coal. Despite the well know affinity for sulphur during combustion, $\mathrm{Zn}$ would appear to have an important glass association (50-60\%) in UK fly ash (Spears, 2004). Kim and Kazonich (2004) found an even distribution of $\mathrm{Zn}$ between the silicate and non silicate fractions.

The leaching pattern of $\mathrm{Zn}$ is similar to other heavy metals discussed above, although $\mathrm{Zn}$ appears to be on the high side of the water solubility. As an amphoteric metal, its solubility against $\mathrm{pH}$ follows a $\mathrm{U}$-shaped curve, reaching a minimum in the $\mathrm{pH}$ 8-10 region (Figure 1 ). The leachability of $\mathrm{Zn}$ in water for alkaline fly ash varies widely, commonly $0.02-0.2 \mathrm{mg} / \mathrm{kg}$ and in all cases below $1 \mathrm{mg} / \mathrm{kg}$ but over the detection limit (Izquierdo et al., 2011; Moreno et al., 
2005; Soco and Kalembkiewicz, 2007). Extractable proportions obtained from a number of water-based leaching tests conducted on Australian and EU alkaline fly ashes consistently ranged between 0.02 and 0.2\% (Kim and Hesbach, 2009; Moreno et al., 2005; Ward et al., 2003). These values are one order of magnitude higher for acid-generating fly ash; acidic conditions enhance the solubility of $\mathrm{Zn}$, although to a much lesser extent than that of $\mathrm{Cu}$. The mobility progressively increases with decreasing $\mathrm{pH}$, attaining extractable proportions of 3-9\% at $\mathrm{pH} \approx 1-2$ (Dreesen et al., 1977; Kim and Hesbach, 2009; Kim et al., 2003).

A weak increase in Zn leachability under strongly alkaline conditions suggests the formation of anionic hydroxo complexes (Figure 1). This amphoteric behaviour has been observed by Dreesen et al. (1977) and van der Sloot (1990). However, other fly ash samples in the literature do not clearly follow this leaching pattern, and data are scattered. The formation of strong complexes in the presence of chloride may also increase Zn solubility (Jones, 1995).

\section{CONCLUSIONS}

The mode of occurrence of trace elements in coal plays a primary role in the mode of occurrence in fly ash and the distribution of elements within ash particles. The elements enriched in the core of fly ash particles are not directly exposed to leaching, whilst surfaceassociated elements are more accessible to leaching in an aqueous environment. Therefore, the mode of occurrence in the parent coal controls to a large extent whether a given element will be immobile or will be easily released to the environment.

The ratio between $\mathrm{Ca}$ and $\mathrm{S}$ dictates the $\mathrm{pH}$ of the water-ash system and so plays the dominant role in the leachability of most elements contained in fly ash. While the alkalinity contributes to attenuating the leachability of a large number of heavy metals, it also enhances the mobility of a few oxyanionic species, i.e. As, $\mathrm{Cr}, \mathrm{Mo}, \mathrm{Sb}, \mathrm{Se}, \mathrm{V}$ and $\mathrm{W}$.

A general feature of $\mathrm{Be}, \mathrm{Cd}, \mathrm{Co}, \mathrm{Cu}, \mathrm{Fe}, \mathrm{Mg}, \mathrm{Mn}, \mathrm{Ni}, \mathrm{Pb}, \mathrm{REE}, \mathrm{Si}, \mathrm{Sn}, \mathrm{Th}, \mathrm{Tl}, \mathrm{U}$ and $\mathrm{Zn}$ is that the minimum solubility is attained in the $\mathrm{pH}$ 7-10 region. These elements can be regarded as being of low concern in alkaline fly ash under environmental conditions (i.e. mildly acidic to alkaline $\mathrm{pH})$. Their leachability is low and not correlated to their concentration in ash, but is $\mathrm{pH}-$ dependent. Therefore, high loads of any of these metals in fly ash due to an anomalously enriched parent coal should not be a limitation for several applications. This statement may not apply to acidic fly ash, since the mobility of the above listed elements rises with decreasing $\mathrm{pH}$.

By contrast, oxyanionic-forming species, i.e. As, B, Cr, Mo, Sb, Se, V and W, display the maximum leachability in the $\mathrm{pH}$ 7-10 range. In the light of the pronounced mobility reported throughout the literature, special consideration should be given to these elements in disposal 
schemes involving alkaline fly ash. Out of them, the main concern should be directed towards As, B, Cr, Mo and Se. These species stand out as potentially harmful for both vegetation and animals, as well as for their high water solubility and therefore their mobility in surface and groundwaters. In the presence of $\mathrm{Ca}$, the leachability of $\mathrm{As}$ and $\mathrm{V}$ is attenuated due to the occurrence of solubility limiting phases. Ettringite shows a great potential for metalloid scavenging, due to its strong affinity for capturing $\mathrm{As}, \mathrm{B}, \mathrm{Cr}, \mathrm{Sb}$, Se and $\mathrm{V}$ into its lattice. However, it must be stressed that (i) the formation of ettringite is not immediate and hence it is especially relevant in long-term exposure scenarios (ii) ettringite is unstable with respect to recarbonation reactions, and thus cannot be viewed as being an ultimate sink for oxyanions in exposed surface environments (Jones, 1995).

\section{REFERENCES}

ABETRAP-ABatement of Emission of TRace Pollutants by FGD from co-combustion and environmental characteristics of by-products. 2006-2009. RFCR-CT-2006-00006 Final Report.

Álvarez-Ayuso, E., Querol, X., 2008. Study of the use of coal fly ash as an additive to minimise fluoride leaching from FGD gypsum for its disposal. Chemosphere 71, 140-146.

Baba, A., Kaya, A., 2004. Leaching characteristics of solid wastes from thermal power plants of western Turkey and comparison of toxicity methodologies. Journal of Environmental Management 73, 199-207.

Boyd, R.J., 2002. The partitioning behaviour of boron from tourmaline during ashing of coal. International Journal of Coal Geology 53, 43-54.

Chandler, A.J., Eighmy, T.T., Hartlén, J., Kosson, D.S., Sawell S.E., Sloot, H., Vehlow, J., 1997. Municipal solid waste incinerator residues. Studies in Environmental Science 67, Elsevier.

Cornelis, G., Johnson, C.A., Gerven, T.V., Vandecasteele, C., 2008. Leaching mechanisms of oxyanionic metalloid and metal species in alkaline solid wastes: A review. Applied Geochemistry 23, 955-976.

Cox, J.A., Lundquist, G.L., Przyjazny, A., Schmulbach, C.D., 1978. Leaching of boron from coal ash. Environmental Science and Technology 12, 722-723.

de Groot, G.J., Wijkstra, J., Hoede, D., Van der Sloot, H.A., 1989. Leaching characteristics of selected elements from coal fly ash as a function of the acidity of the contact solution and the liquid/solid ratio. In Cote, P.L., Gilliam, T.M. (Eds.), Environmental Aspects of Stabilization and Solidification of Hazardous and Radioactive Wastes. USA, American Society for Testing and Materials, p.p. $170-183$.

Dreesen, D.R., Gladney, E.S., Owens, J.W., 1977. Comparison of levels of trace elements extracted from fly ash and levels found in effluent waters from a coal-fired power plant. Environmental Science and Technology 11, 1017-1019.

Dubikova, M., Jankowski, J., Ward, C.R., French, D., 2006. Modelling element mobility in waterfly ash interactions. Co-operative Research Centre for Coal in Sustainable Development, Research Report 61, 61 pp. http://pandora.nla.gov.au/pan/64389/200808281328/www.ccsd.biz/publications/635.html

Dudas, M.J., 1981. Long-term leachability of selected elements from fly ash. Environmental Science and Technology 15, 840-843.

EPRI (Electric Power Research Institute), 1998. Leaching of inorganic constituents from coal combustion by-products under field and laboratory conditions: Volume 1. EPRI, Palo Alto, CA: 1998. Report TR-111773-V1. 
EPRI (Electric Power Research Institute), 2006. Chemical Constituents in Coal Combustion Product Leachate: Beryllium. EPRI, Palo Alto, CA: 2006. 1012583.

EPRI (Electric Power Research Institute), 2008a. Chemical Constituents in Coal Combustion Product Leachate: Thallium, Technical Report 1016801.

EPRI (Electric Power Research Institute), 2008b. The Leaching Behavior of Arsenic and Selenium from Coal Fly Ash, EPRI, Palo Alto, CA: 2008. 1015545.

Federal Register, 2010. Hazardous and Solid Waste Management System; Identification and Listing of Special Wastes; Disposal of Coal Combustion Residuals from Electric Utilities; 75 (118), 35128-35264.

Finkelman, R.B., 1995. Modes of occurrence of environmentally-sensitive trace elements in coal. In Swaine, D.J., Goodarzi, F. (Eds), Environmental Aspects of Trace Elements in Coal, Springer.

Foscolos, A.E., Goodarzi, F., Koukouzas, C.N., Hatziyannis, G., 1989. Reconnaissance study of mineral matter and trace elements in Greek lignites. Chemical Geology 76, 107-130.

Freyer, D., Voigt, W., 2003. Crystallization and phase stability of CaSO4 and CaSO4 - based salts. Monatshefte für Chemie 134, 693-719.

Fruchter, J.S., Rai, D., Zachara, J.M., 1990. Identification of solubility-controlling solid phases in a large fly ash field lysimeter. Environmental Science and Technology 24, 1173-1179.

Georgakopoulos, A., Filippidis, A., Kassoli-Fournaraki, A., Fernández-Turiel, J.L., Llorens, J.F., Mousty, F., 2002. Leachability of major and trace elements of fly ash from Ptolemais power station, Northern Greece. Energy Sources 24, 103-113.

Goodarzi, F., Huggins, F.E., Sanei, H., 2008. Assessment of elements, speciation of As, Cr, Ni and emitted $\mathrm{Hg}$ for a Canadian power plant burning bituminous coal. International Journal of Coal Geology 74, 1-12.

Grisafe, D.A., Angino, E.E., Smith, S.M., 1988. Leaching characteristics of a high-calcium fly ash as a function of $\mathrm{pH}$ : a potential source of selenium toxicity. Applied Geochemistry 3, 601-608.

Hansen, L.D., Silberman, D., Fisher, G.L., 1981. Crystalline components of stack-collected, sizefractionated coal fly ash: Environmental Science and Technology 15, 1057-1062.

Hassett, D.J., Pflughoeft-Hassett, D.F., Heebink, L.V., 2005, Leaching of CCBs: observations from over 25 years of research. Fuel, 84, 1378-1383.

Hjelmar, O., 1990. Leachate from land disposal of coal fly ash: Waste Management and Research 8, 429-449.

Hower, J.C., Rathbone, R.F., Robertson, J.D., Peterson, G., Trimble, A.S., 1999. Petrology, mineralogy, and chemistry of magnetically-separated sized fly ash. Fuel 78, 197-203.

Huggins, F.E., Huffman, G.P., 2004. How do lithophile elements occur in organic association in bituminous coals? International Journal of Coal Geology 58, 193-204.

Huggins, F.E., Najih, M., Huffman, G.P., 1999. Direct speciation of chromium in coal combustion by-products by X-ray absorption fine-structure spectroscopy. Fuel, 78, 233-242.

Huggins, F.E., Shah, N., Huffman, G.P., Kolker, A., Crowley, S., Palmer, C.A., Finkelman, R.B., 2000a. Mode of occurrence of chromium in four US coals. Fuel Processing Technology 63, 7992.

Huggins, F.E., Shah, N., Huffman, G.P., Robertson, J.D., 2000b. XAFS spectroscopic characterization of elements in combustion ash and fine particulate matter. Fuel Processing Technology 65-66, 203-218.

Iwashita, A., Sakaguchi, Y., Nakajima, T., Takanashi, H., Ohki, A., Kambara, S., 2005. Leaching characteristics of boron and selenium for various coal fly ashes. Fuel 84, 479-485.

Iyer, R., 2002, The surface chemistry of leaching coal fly ash. Journal of Hazardous Materials 93, 321-329. 
Izquierdo, M., Koukouzas, N., Touliou, S., Panopoulos, K.D., Querol, X., Itskos, G., 2011. Geochemical controls on leaching of lignite-fired combustion by-products from Greece. Applied Geochemistry, in press.

Izquierdo, M., Moreno, N., Font, O., Querol, X., Alvarez, E., Antenucci, D., Nugteren, H., Luna, Y., Fernández-Pereira, C., 2008. Influence of the co-firing on the leaching of trace pollutants from coal fly ash. Fuel 87, 1958-1966.

James, W.D., Graham, C.C., Glascock, M.D., Hanna, A.S.G., 1982. Water-leachable boron from coal ashes. Environmental Science and Technology 16, 195-197.

Jankowski, J., Ward, C.R., French, D., 2004. Preliminary assessment of trace element mobilisation from Australian fly ashes. Co-operative Research Centre for Coal in Sustainable Development, Research Report 45, 44 pp. http://pandora.nla.gov.au/pan/64389/200808281328/www.ccsd.biz/publications/425.html

Jankowski, J., Ward, C.R., French, D., Groves, S., 2006. Mobility of trace elements from selected Australian fly ashes and its potential impact on aquatic ecosystems. Fuel 85, 243-256.

Jones, D.R., 1995. The leaching of major and trace elements from coal ash. In: Swaine, D.J., Goodarzi, F. (Eds), Environmental Aspects of Trace Elements in Coal, Springer.

Kim, A. G., 2002. CCB leaching summary: survey of methods and results, in Vories, K.C., Throgmorton, D. (Eds), Proceedings of Coal Combustion By-Products and Western Coal Mines: A Technical Interactive Forum, U.S. Department of Interior, Office of Surface Mining and Coal Research Center, Southern Illinois University. http://www.mcrcc.osmre.gov/MCR/Resources/ccb/PDF/CCB_and_Western_Coal_Mines.pdf

Kim, A.G., Hesbach, P., 2009. Comparison of fly ash leaching methods. Fuel 88, 926-937.

Kim, A.G., Kazonich, G., 2004. The silicate/non-silicate distribution of metals in fly ash and its effect on solubility. Fuel 83, 2285-2292.

Kim, A.G., Kazonich, G., Dahlberg, M., 2003. Relative solubility of cations in class F fly ash: Environmental Science and Technology 37, 4507-4511.

Kukier, U., Ishak, C.F., Sumner, M.E., Miller, W.P., 2003. Composition and element solubility of magnetic and non-magnetic fly ash fractions. Environmental Pollution 123, 255-266.

Kumarathasan, P., McCarthy, G.J., Hassett, D.J., Pflughoeft-Hassett, D.F., 1990. Oxyanion substituted ettringites: synthesis and characterization, and their potential role in immobilization of As, B, Cr, Se, and V., In Materials Research Society Symposia 178, 83-104.

Medina, A., Gamero, P., Querol, X., Moreno, N., De León, B., Almanza, M., Vargas, G., Izquierdo, M., Font, O., 2010. Fly ash from a Mexican mineral coal I: Mineralogical and chemical characterization. Journal of Hazardous Materials 181, 82-90.

Meij, R., 1995, The distribution of trace elements during the combustion of coal. In: Swaine, D.J., Goodarzi, F. (Eds), Environmental Aspects of Trace Elements in Coal, Springer.

Miravet, R., Lopez-Sanchez, J.F., Rubio, R., 2006. Leachability and analytical speciation of antimony in coal fly ash. Analytica Chimica Acta 576, 200-206.

Moreno, N., Querol, X., Andrés, J.M., Stanton, K., Towler, M., Nugteren, H., JanssenJurkovicová, M., Jones, R., 2005. Physico-chemical characteristics of European pulverized coal combustion fly ashes. Fuel 84, 1351-1363.

Nathan, Y., Dvorachek, M., Pelly, I., Mimran, U., 1999. Characterization of coal fly ash from Israel. Fuel 78, 205-213.

Négrel, P., Roy, S., 2002. Investigating the sources of the labile fraction in sediments from silicate-drained rocks using trace elements, and strontium and lead isotopes. Science of The Total Environment 298, 163-181. 
Nugteren, H., 2010. Secondary industrial minerals from coal fly ash and aluminium anodising waste solutions. PhD thesis. Faculty of Applied Sciences. Delft, Delft University of Technology.

Nugteren, H.W., Janssen-Jurkovícová, M., Scarlett, B., 2001. Improvement of environmental quality of coal fly ash by applying forced leaching. Fuel 80, 873-877.

Otero-Rey, J.R., Mato-Fernández, M.J., Moreda-Piñeiro, J., Alonso-Rodríguez, E., MuniateguiLorenzo, S., López-Mahía, P., Prada-Rodríguez, D., 2005. Influence of several experimental parameters on As and Se leaching from coal fly ash samples. Analytica Chimica Acta 531, 299305.

Pflughoeft-Hassett, D.F., 2004. Leaching characteristics of fly ash-activated carbon from mercury control technologies. Final report 2004-EERC-12-03. Energy \& Environmental Research Center. Grand Forks, ND, December 2004.

Piekos, R., Paslawska, S., 1998. Leaching characteristics of fluoride from coal fly ash. Fluoride $31,5$.

Pires, M., Querol, X., 2004. Characterization of Candiota (South Brazil) coal and combustion byproduct. International Journal of Coal Geology 60, 57-72.

Praharaj, T., Powell, M.A., Hart, B.R., Tripathy, S., 2002. Leachability of elements from subbituminous coal fly ash from India. Environmental International 27, 609-615.

Querol, X., Fernández-Turiel, J., López-Soler, A., 1995. Trace elements in coal and their behaviour during combustion in a large power station. Fuel 74, 331-343.

Querol, X., Juan, R., Lopez-Soler, A., Fernandez-Turiel, J.L., Ruiz, C.R., 1996. Mobility of trace elements from coal and combustion wastes. Fuel 75, 821-838.

Querol, X., Alastuey, A., Lopez-Soler, A., Plana, F., Fernandez-Turiel, J.L., Zeng, R., Xu, W., Zhuang, X., Spiro, B., 1997a. Geological controls on the mineral matter and trace elements of coals from the Fuxin basin, Liaoning Province, northeast China. International Journal of Coal Geology 34, 89-109.

Querol, X., Whateley, M.K.G., Fernández-Turiel, J.L., Tuncali, E., 1997b. Geological controls on the mineralogy and geochemistry of the Beypazari lignite, central Anatolia, Turkey. International Journal of Coal Geology 33, 255-271.

Querol, X., Umaña, J.C., Alastuey, A., Ayora, C., Lopez-Soler, A., Plana, F., 2001. Extraction of soluble major and trace elements from fly ash in open and closed leaching systems. Fuel 80, 801-813.

Ribeiro, J., Valentim, B., Ward, C., Flores, D., 2011. Comprehensive characterization of anthracite fly ash from a thermo-electric power plant and its potential environmental impact. International Journal of Coal Geology 86, 204-212.

Rice, C.A., Breit, G.N., Fishman, N.S., Bullock, J.H., 1999. Leachability of Trace Elements in Coal and Coal Combustion Wastes. Proceedings of 24th International Technical Conference on Coal Utilization and Fuel Systems, Clearwater, Florida, March 8-11, 1999 (Coal Slurry Technology Assn, Washington, DC), pp. 355-366.

Riley, K.W., French, D.H., Lambropoulos, N.A., Farrell, O.P., Wood, R.A., Huggins, F.E., 2007. Origin and occurrence of selenium in some Australian coals. International Journal of Coal Geology 72, 72-80.

Roy, W.R., Griffin, R.A., 1984. Illinois basin coal fly ashes. 2. Equilibria relationships and qualitative modeling of ash-water reactions. Environmental Science and Technology 18, 739742.

Ruppert, L., Finkelman, R., Boti, E., Milosavljevic, M., Tewalt, S., Simon, N., Dulong, F., 1996. Origin and significance of high nickel and chromium concentrations in pliocene lignite of the Kosovo Basin, Serbia. International Journal of Coal Geology 29, 235-258. 
Sanchez, F., Keeney, R., Kosson, D., Delapp, R., (2006). Characterization of mercury-enriched coal combustion residues from electric utilities using enhanced sorbents for mercury control, Contract No. EP-C-04-023, Work Assignment 1-31, EPA-600/R-06/0008.

Sear, L.K.A., Weatherley, A. J., Dawson, A. R., 2003. The environmental impacts of using fly ash - the UK producers perspective. 2003 International Ash Utilization Symposium: Kentucky, Lexington.

Seidel, A., Zimmels, Y., 1998. Mechanism and kinetics of aluminum and iron leaching from coal fly ash by sulfuric acid. Chemical Engineering Science 53, 3835-3852.

Shah, P.S., V. Prince, K. Nelson, P. F., 2008. Speciation of As, Cr, Se and $\mathrm{Hg}$ under coal fired power station conditions. Fuel 87, 1859-1869.

Soco, E., Kalembkiewicz, J., 2007. Investigations of sequential leaching behaviour of $\mathrm{Cu}$ and $\mathrm{Zn}$ from coal fly ash and their mobility in environmental conditions. Journal of Hazardous Materials $145,482-487$.

Soco, E., Kalembkiewicz, J., 2009. Investigations on $\mathrm{Cr}$ mobility from coal fly ash. Fuel 88, 1513-1519.

Spears, D.A., 2004. The use of laser ablation inductively coupled plasma-mass spectrometry (LA ICP-MS) for the analysis of fly ash. Fuel 83, 1765-1770.

Spears, D.A., Martinez-Tarrazona, M.R., 2004. Trace elements in combustion residues from a UK power station. Fuel 83, 2265-2270.

Swaine, D.J., 1990. Trace Elements in Coal. London, Butterworth-Heinemann Ltd.

Swaine, D.J., 1995. The formation, composition and utilisation of fly ash. In: Swaine, D.J., Goodarzi, F. (Eds), Environmental Aspects of Trace Elements in Coal, Springer.

Tishmack, J.K., 1996. Bulk chemical and mineralogical characteristics of coal combustion byproducts. Proceedings from Coal Combustion byproducts Associated with Coal Mining Interactive Forum: Southern Illinois University, Carbondale, p. 13-20.

Turner, R.R., 1981. Oxidation state of arsenic in coal ash leachate. Environmental Science and Technology 15, 1062-1066.

Ugurlu, A., 2004. Leaching characteristics of fly ash: Environmental Geology 46, 890-895.

van der Hoek, E.E., Bonouvrie, P.A., Comans, R.N.J., 1994. Sorption of As and Se on mineral components of fly ash: Relevance for leaching processes. Applied Geochemistry 9, 403-412.

van der Sloot, H.A., 1990. Leaching behaviour of waste and stabilized waste materials; characterization for environmental assessment purposes: Waste Management and Research 8, 215-228.

van der Sloot, H.A., Heasman, L., Quevauviller, P., 1997. Harmonization of Leaching/Extraction Tests. Studies in Environmental Science, Volume 70: Amsterdam, Elsevier.

Vassilev, S.V., Vassileva, C.G., 1996. Mineralogy of combustion wastes from coal-fired power stations. Fuel Processing Technology 47, 261-280.

Ward, C.R., French, D., Jankowski J., 2003. Comparative evaluation of leachability test methods and element mobility for selected Australian fly ash samples. Co-operative Research Centre for Coal in Sustainable Development, Technical Note 22, 22 pp. http://pandora.nla.gov.au/pan/64389/20080828-1328/www.ccsd.biz/publications/694.html

Ward, C.R., French, D., Jankowski, J., Dubikova, M., Li, Z., Riley, K.W., 2009. Element mobility from fresh and long-stored acidic fly ashes associated with an Australian power station. International Journal of Coal Geology 80, 224-236.

Warren, C.J., Dudas, M.J., 1988. Leaching behaviour of selected trace elements in chemically weathered alkaline fly ash. Science of The Total Environment 76, 229-246. 
Warren, C.J., Dudas, M.J., 1989. Leachability and partitioning of elements in ferromagnetic fly ash particles. Science of The Total Environment 83, 99-111.

WWCCPN, 2011, World-Wide Coal Combustion Products Network, http://www.wwccpn.org/. Last access: 2011.

Yudovich, Y.E., Ketris, M.P., 2005. Arsenic in coal: A review. International Journal of Coal Geology 61, 141-196.

Yudovich, Y.E., Ketris, M.P., 2006. Selenium in coal: A review. International Journal of Coal Geology 67, 112-126.

Zandi, M., Russell, N., 2007. Design of a Leaching Test Framework for Coal Fly Ash Accounting for Environmental Conditions. Environmental Monitoring and Assessment 131, 509-526. 


\section{FIGURE CAPTIONS}

Figure 1. General trends in the leaching behaviour of selected elements vs pH after Chandler et al. (1997), de Groot (1989), Dubikova et al. (2006), Jankowski et al. (2004), Jones (1995), Moreno et al. (2005), van der Sloot (1990) and Zandi and Russell (2007).

Figure 2. Release pattern of calcium and selected oxyanionic-forming elements. Data obtained from column tests conducted on a mildly alkaline and low Ca fly ash (A), moderately alkaline and moderately Ca-rich fly ash (B) and strongly alkaline and Ca-rich fly ash (C). After Querol et al. (2001). 
Figure 1.
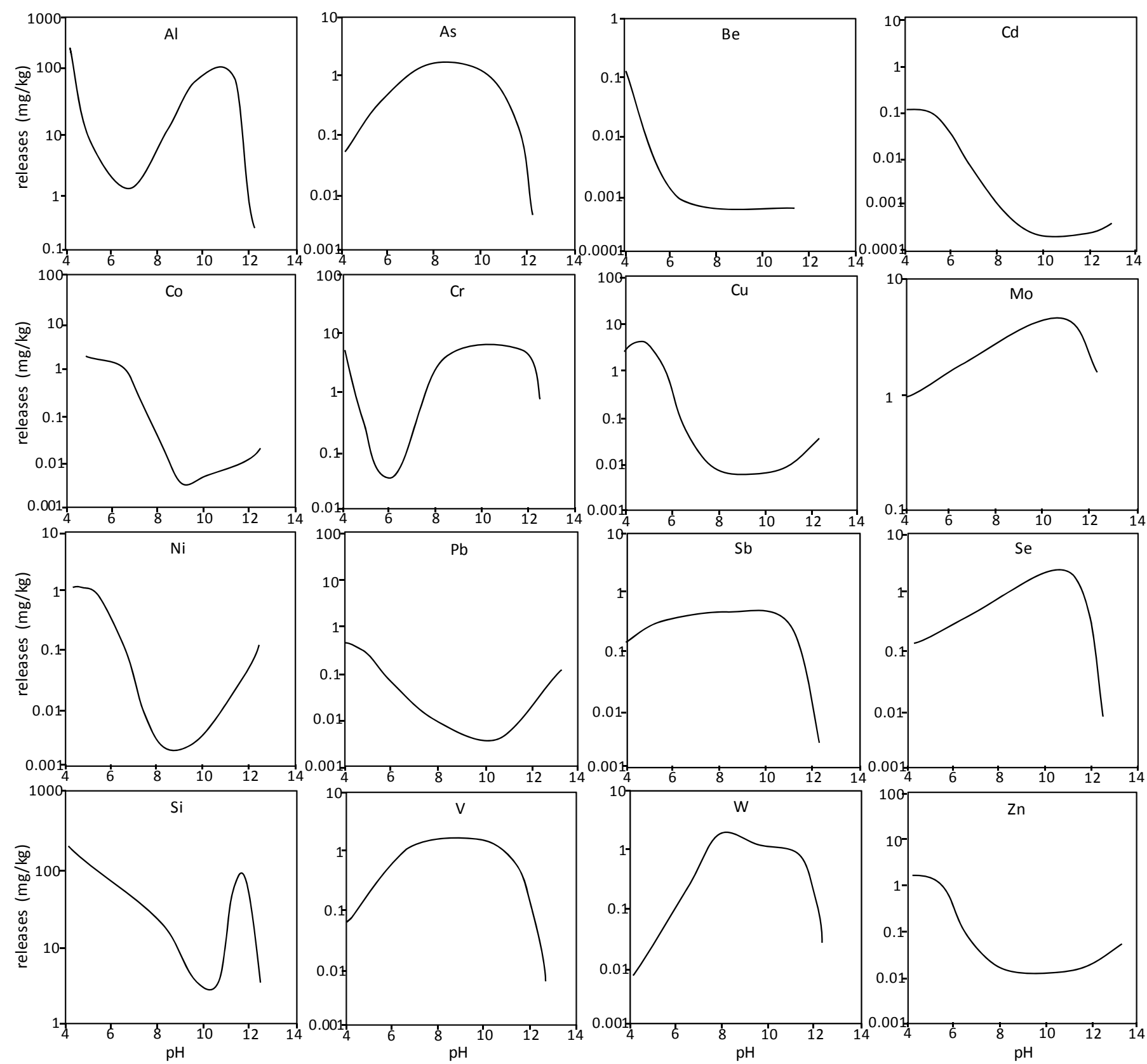
Figure 2.
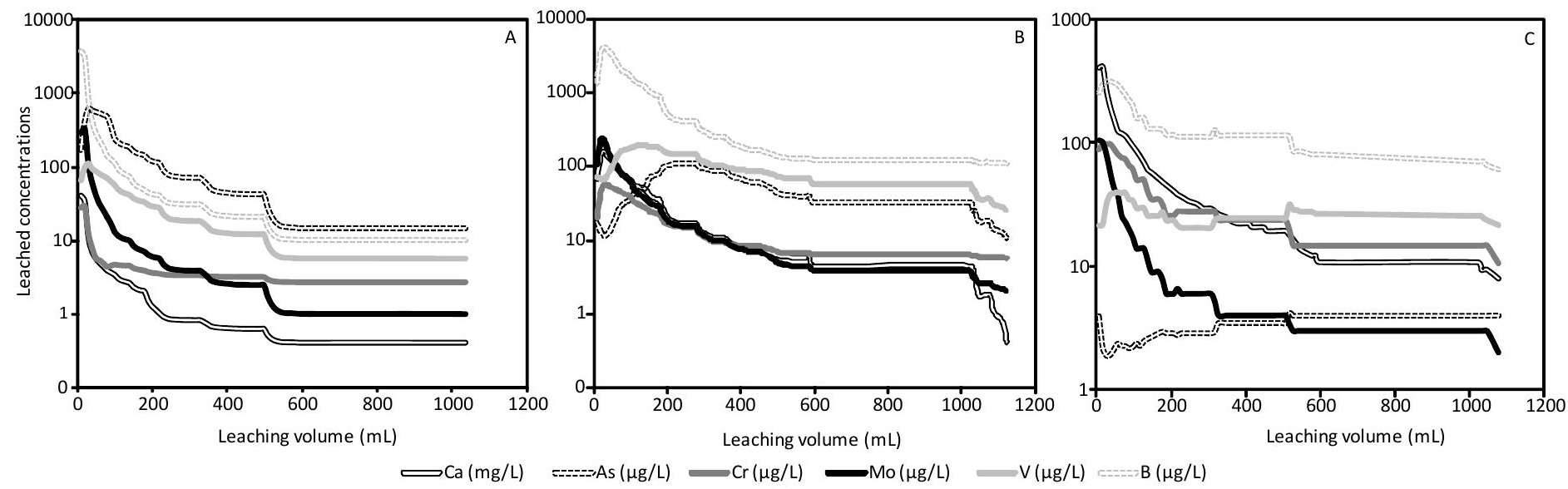

$=\mathrm{Cr}(\mu \mathrm{g} / \mathrm{L}) \longrightarrow \mathrm{Mo}(\mu \mathrm{g} / \mathrm{L})=\mathrm{V}(\mu \mathrm{g} / \mathrm{L}) \quad \mathrm{B}(\mu \mathrm{g} / \mathrm{L})=\mathrm{B} / \mathrm{L})$ 